\title{
2. PROVENANCE AND DISPERSAL PATTERNS OF SEDIMENTS IN THE TURBIDITE WEDGE OF NANKAI TROUGH ${ }^{1}$
}

\author{
Michael B. Underwood, ${ }^{2}$ Robert Orr, ${ }^{2}$ Kevin Pickering, ${ }^{3}$ and Asahiko Taira ${ }^{4}$
}

\begin{abstract}
Drill core recovered at Ocean Drilling Program Site 808 (Leg 131) proves that the wedge of trench sediment within the central region of the Nankai Trough comprises approximately $600 \mathrm{~m}$ of hemipelagic mud, sandy turbidites, and silty turbidites. The stratigraphic succession thickens and coarsens upward, with hemipelagic muds and volcanic-ash layers of the Shikoku Basin overlain by silty and sandy trench-wedge deposits. Past investigations of clay mineralogy and sand petrography within this region have led to the hypothesis that most of the detritus in the Nankai Trough was derived from the Izu-Honshu collision zone and transported southwestward via axial turbidity currents. Shipboard analyses of paleocurrent indicators, on the other hand, show that most of the ripple cross-laminae within silty turbidites of the outer marginal trench-wedge facies are inclined to the north and northwest; thus, many of the turbidity currents reflected off the seaward slope of the trench rather than moving straight down the trench axis. Shore-based analyses of detrital clay minerals demonstrate that the hemipelagic muds and matrix materials within sandy and silty turbidites are all enriched in illite; chlorite is the second-most abundant clay mineral, followed by smectite. In general, the relative mineral percentages change relatively little as a function of depth, and the hemipelagic clay-mineral population is virtually identical to the turbidite-matrix population.

Comparisons between different size fractions $(<2 \mu \mathrm{m}$ and $2-6 \mu \mathrm{m})$ show modest amounts of mineral partitioning, with chlorite content increasing in the coarser fraction and smectite increasing in the finer fraction. Values of illite crystallinity index are consistent with conditions of advanced anchimetamorphism and epimetamorphism within the source region. Of the three mica polytypes detected, the $2 \mathrm{M}_{1}$ variety dominates over the $1 \mathrm{M}$ and $1 \mathrm{M} d$ polytypes; these data are consistent with values of illite crystallinity. Measurements of mica $b_{0}$ lattice spacing show that the detrital illite particles were eroded from a zone of intermediate-pressure metamorphism. Collectively, these data provide an excellent match with the lithologic and metamorphic character of the Izu-Honshu collision zone. Data from Leg 131, therefore, confirm the earlier interpretations of detrital provenance. The regional pattern of sediment dispersal is dominated by a combination of southwest-directed axial turbidity currents, radial expansion of the axial flows, oblique movement of suspended clouds onto and beyond the seaward slope of the Nankai Trough, and flow reflection back toward the trench axis.
\end{abstract}

\section{INTRODUCTION}

The Nankai Trough region of southwest Japan (Fig. 1) is one of the most thoroughly studied examples of late Cenozoic trench sedimentation and accretionary prism tectonics. Numerous geophysical surveys and conventional coring transects have been completed in this region over the past two decades (e.g., Boggs, 1984; Kagami, 1985; Le Pichon et al., 1987a, 1987b; Okuda and Honza, 1988; Moore et al., 1990). Four Deep Sea Drilling Project/Ocean Drilling Program (DSDP/ODP) legs $(31,58,87 \mathrm{~A}$, and 131$)$ have included sites in the Nankai Trough and the adjacent Shikoku Basin (Karig, Ingle, et al., 1975; Klein, Kobayashi, et al., 1980; Kagami, Karig, Coulbourn, et al., 1986; Taira, Hill, Firth, et al., 1991). When compared to other well-studied subduction margins such as Barbados (Moore et al., 1982a, 1988) and the nearby Japan Trench (von Huene and Arthur, 1982; von Huene et al., 1982; Cadet et al., 1987), the amount of terrigenous sediment influx is relatively high offshore from Kyushu, Shikoku, and the Kii Peninsula of Honshu. The Nankai stratigraphy, therefore, serves as an effective modern analog for sandstone-rich accretionary terranes such as the Franciscan Complex of California (Bachman, 1982; Underwood, 1984; Blake et al, 1985), the Kodiak Islands of Alaska (Moore et al., 1983; Byrne, 1984; Sample and Moore, 1987), and the Shimanto Belt of Japan (Taira, 1985a; Taira et al., 1988; Agar, 1990; DiTullio and Byrne, 1990; Hibbard and Karig, 1990).

\footnotetext{
${ }^{1}$ Hill, I.A., Taira, A., Firth, J.V., et al., 1993. Proc. ODP, Sci. Results, 131: College Station, TX (Ocean Drilling Program).

${ }^{2}$ Department of Geological Sciences, University of Missouri, Columbia, MO 65211, U.S.A.

${ }^{3}$ Department of Geology, University of Leicester, University Road, Leicester LE1 $7 \mathrm{RH}$, United Kingdom.

${ }^{4}$ Ocean Research Institute, University of Tokyo, 1-15-1 Minamidai, Nakano-ku, Tokyo 164, Japan.
}

The most recent drilling effort, ODP Leg 131, was designed to emphasize variations in structural fabric, physical properties, and aqueous geochemistry within the toe of the Nankai accretionary prism; an additional priority was to collect in-situ measurements via downhole logs (Shipboard Scientific Party, 1991a). Although logging efforts met with limited success, the cores recovered from Site 808 by advanced hydraulic piston corer, (APC), extended core barrel (XCB), and rotary core barrel (RCB) methods allowed documentation, in unprecedented detail, of accretionary-prism stratigraphy and sedimentary facies relations (Fig. 2).

From a sedimentologic perspective, three general aspects of Site 808 merit mention. First, the holes were spudded on the landward trench slope less than $150 \mathrm{~m}$ above the floor of the present-day trench (Moore and Shipboard Scientific Party, 1991). Except for an upper carapace of slope deposits (roughly $20 \mathrm{~m}$ thick), all of the recovered material either has been offscraped and incorporated into the toe of the accretionary prism or thrust beneath the toe along the basal décollement (Moore, Karig, et al., 1991b; Taira, Hill, Firth, et al., 1991). Duplication of the stratigraphy also is evident along the frontal thrust of the prism, with approximately $140 \mathrm{~m}$ of vertical displacement (Fig. 2). Second, whereas previous DSDP drill sites were located farther down the axial gradient and closer to the western edge of the trench, Site 808 was drilled near the center of the basin (Fig. 1), along the trend of an extinct spreading center that was responsible for the formation of oceanic crust within Shikoku Basin (Chamot-Rooke et al., 1987; Le Pichon et al., 1987a). Even though the basement relief has been buried within the trench, the proximity to the inherited bathymetric high clearly affected rates of sedimentation outboard of the trench (Pickering et al., this volume). In fact, one reason for selecting the site was because the total sediment thickness is at a regional minimum above the basement high, and this allowed penetration of the décollement at a depth of approximately $950 \mathrm{~m}$ below 


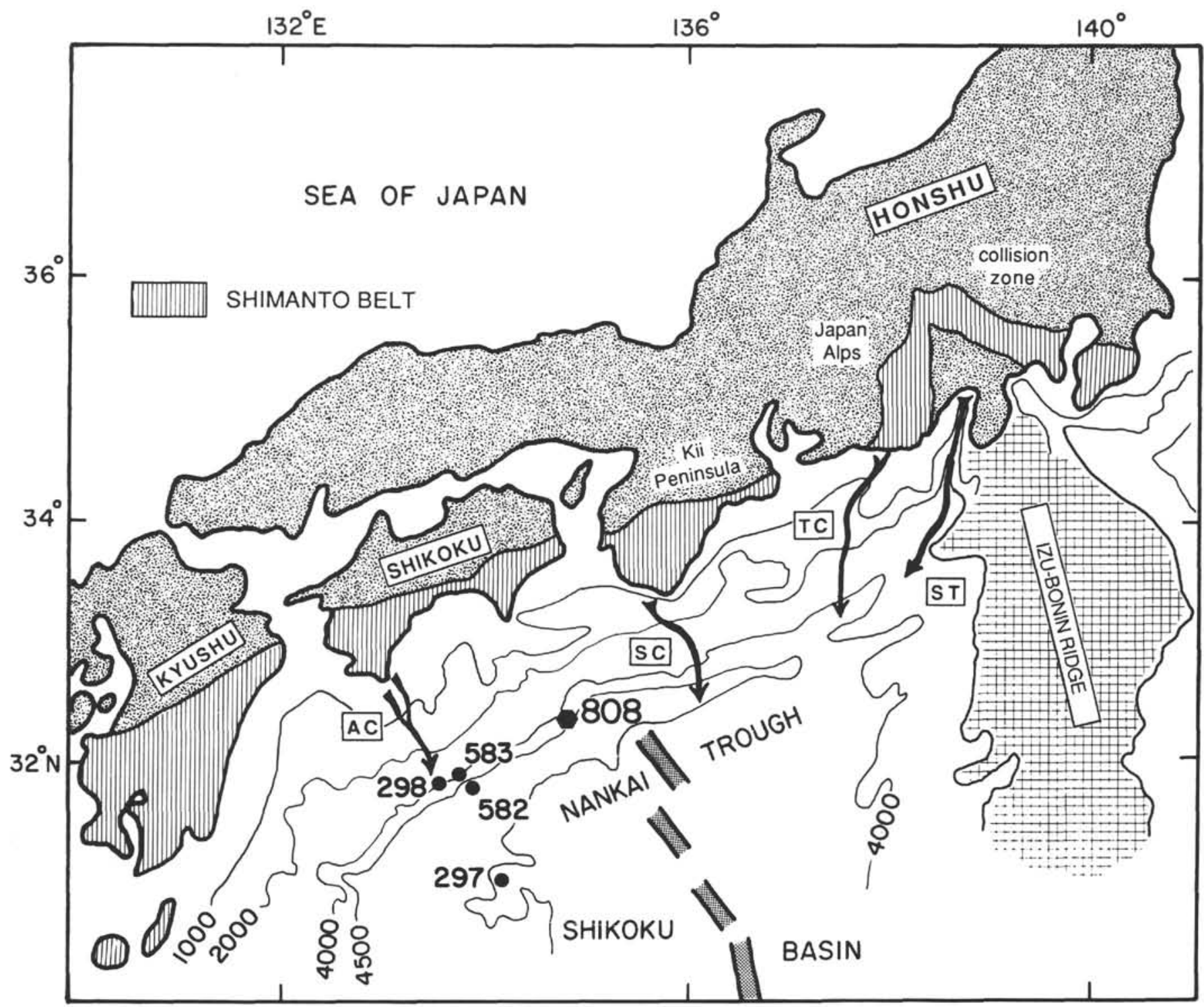

Figure 1. Index map of the Nankai Trough and Shikoku Basin region showing the location of Site 808, as well as previous drilling sites associated with DSDP Legs 31 and 87A. Bathymetric contours are in meters. Note the schematic representation of the central ridge of Shikoku Basin. Arrows signify major sediment conduits. $\mathrm{ST}=$ Suruga Trough; $\mathrm{TC}=$ Tenryu Canyon; $\mathrm{SC}=$ Shiono-misaki Canyon; $\mathrm{AC}=$ Ashizuri Canyon. Onshore regions underlain by rocks of the Shimanto Belt are shown with vertical ruled pattern.

seafloor (mbsf). Third, because of the youthful nature of the subducting oceanic crust (approximately $15 \mathrm{Ma}$ ), and the location of the drill site near the extinct spreading axis, heat flow is unusually high for an accretionary prism (Yamano et al., 1984). The average geothermal gradient recorded at Site 808 is approximately $110^{\circ} \mathrm{C} / \mathrm{km}$ (Shipboard Scientific Party, 1991b; Yamano et al., 1992), and this high gradient exerts a considerable influence on sediment diagenesis, particularly at depths below about $600 \mathrm{~m}$.

To avoid the dilemma of discriminating between detrital and diagenetic clay-mineral suites, the focus of this paper is restricted to the trench-wedge facies within the upper $620 \mathrm{~m}$ of the stratigraphic column. The subject of sediment diagenesis is treated elsewhere (Underwood et al., this volume). This paper describes the sedimentary petrology of the Nankai trench wedge and places the results of new shore-based analyses of clay minerals within the framework of previously published petrographic and mineralogic data. This new information, together with observations derived from internal sedi- mentary structures and grain fabric, allows us to refine interpretations of detrital provenance and regional sediment dispersal.

\section{PREVIOUS STUDIES}

\section{Lithofacies Trends}

Previous drilling through the toe of the Nankai accretionary prism (Sites 298 and 583) and through the floor of the Nankai Trough (Site 582) demonstrated that the trench fill is dominated by sand turbidites, with interlayers of hemipelagic mud (Moore and Karig, 1976; Coulbourn, 1986). The sedimentary succession recovered at Site 808 likewise displays an overall trend of coarsening and thickening upward (Fig. 2). This strafigraphic pattern is consistent with the paradigm of trench sedimentation, in which fine-grained deposits of the abyssal plain and outer trench-slope environments are overlain progressively by silty then sandy turbidites of the trench wedge as the subducting oceanic plate draws closer to the deformation front (Piper 


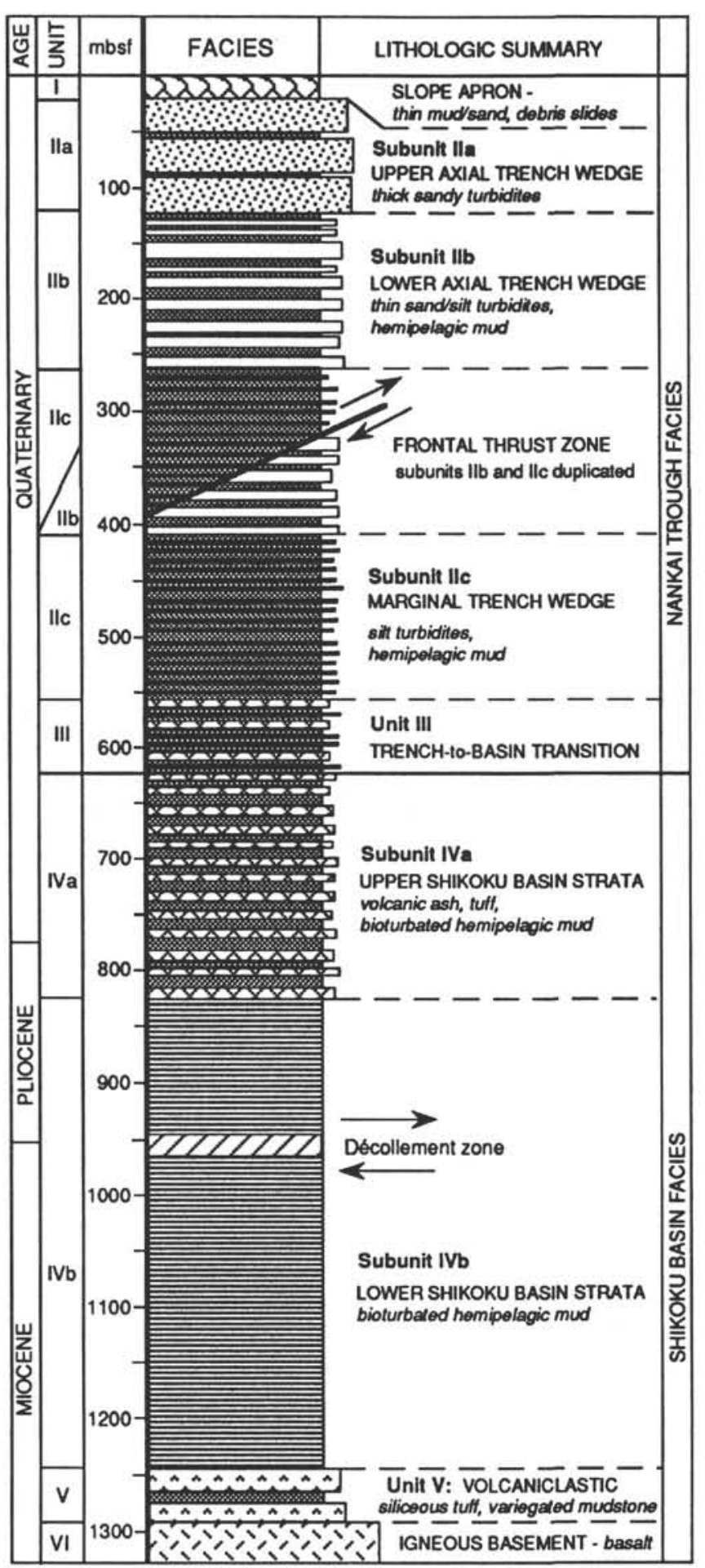

Figure 2. Schematic stratigraphic column for Site 808 , based on detailed shipboard core descriptions, sedimentary facies interpretations, and microfossil control (modified from Shipboard Scientific Party, 1991b).

et al., 1973; Schweller and Kulm, 1978; Thomburg and Kulm, 1987). Core recovery at Site 808 allowed a precise definition of vertical changes in turbidite thickness and texture (Shipboard Scientific Party, 1991b). Rates of sediment accumulation within the trench-wedge facies range from approximately 785 to $1380 \mathrm{~m} / \mathrm{m}$.y. (Shipboard Scientific Party, 1991b). The initiation of outer trench-wedge sedimentation can be recognized by the first appearance (moving upsection) of silty ter- rigenous turbidites at a depth of about $620 \mathrm{mbsf}$ (Fig. 2). These turbidite layers typically display base-absent Bouma sequences complete with ripple cross-lamination. In contrast, the deposits of Shikoku Basin (both beneath the present-day trench wedge and drilled in situ) are dominated by bioturbated hemipelagic mud (White et al., 1980; Coulbourn, 1986). Rates of sediment accumulation within the hemipelagic section at Site 808 range from approximately $45 \mathrm{~m} / \mathrm{m}$.y. to $110 \mathrm{~m} / \mathrm{m}$.y. (Shipboard Scientific Party, 1991b).

The Shikoku Basin deposits at Site 808 can be divided into an upper subunit enriched in volcanic ash layers and a lower subunit that is devoid of volcaniclastic material (Fig. 2). A transitional facies unit displays characteristics of both the outer marginal trench wedge (silty turbidites) and the upper part of the ${ }^{-S h i k o k u ~ B a s i n ~ s e c t i o n ~(a s h ~}$ layers). On a regional scale, one complication to this simple coarsening-upward facies trend is the enigmatic occurrence of graded silt and sand deposits at Site 297 (Fig. 1); these Pliocene deposits were encountered beginning at depths of about $330 \mathrm{~m}$ beneath the ash-rich hemipelagic subunit of the Shikoku Basin (Shipboard Scientific Party, 1975). One explanation for the terrigenous influx is that, prior to the early Pliocene, the bathymetric relief of Nankai Trough was not sufficient to prevent spillover of turbidity currents into the adjacent Shikoku Basin (Karig, 1975). The absence of coeval turbidites within the Pliocene section at Site 808 shows that the phenomena were not basinwide; furthermore, the terrigenous sands and silts did not extend into more distal portions of the basin (e.g., Sites 442, 443, and 444).

\section{Sand Petrography}

Previous petrographic analyses of turbidite sand associated with the Nankai Trough have led the conclusion that most of this detritus was initially funneled through Suruga Trough (Fig. 1) before moving southwestward down the axial gradient (Taira and Niitsuma, 1986; De Rosa et al., 1986). Shipboard point counts of unstained thin sections (following the Gazzi-Dickinson method, as described by Ingersoll et al., 1984) indicate that the turbidite sands at Site 808 are enriched in a wide variety of neovolcanic and paleovolcanic rock fragments (with lathwork, microlitic, felsitic, and vitric textures); in addition, the sands contain numerous sedimentary rock fragments (mostly shale and mudstone), fresh euhedral plagioclase, both monocrystalline and polycrystalline quartz (chert), plus minor amounts of metamorphic rock fragments (Shipboard Scientific Party, 1991b). Based on comparisons with data from modern fluvial and nearshore sands (Taira and Niitsuma, 1986), we would agree that the detritus at Site 808 probably was derived from a source region that includes the Fuji River drainage basin and perhaps the Tenryu River drainage. This lithologic mixture in the source terrane was created by simultaneous volcanism and uplift of previously accreted materials during the collision between the Izu-Bonin Arc and the Honshu Arc (Ogawa et al., 1985; Toriumi and Arai, 1989).

At Site 808, the average values of total quartz (Q), total feldspar (F), and total unstable lithic fragments (L) are Q-22, F-20, and L-58, respectively (Fig. 3). Unstable lithic fragments are further subdivided as follows: volcanic rock fragments $\left(\mathrm{L}_{v}\right)$, sedimentary rock fragments $\left(\mathrm{L}_{\mathrm{s}}\right)$, and metamorphic rock fragments $\left(\mathrm{L}_{\mathrm{m}}\right)$. The average values for these lithic modes are $\mathrm{L}_{\mathrm{v}}-48, \mathrm{~L}_{\mathrm{s}}-46$, and $\mathrm{L}_{\mathrm{m}}-6$, respectively. If all of the polycrystalline grains are considered, the average modes are $\mathrm{Q}_{\mathrm{p}}-10$, $\mathrm{L}_{\mathrm{v}}-44$, and $\mathrm{L}_{\mathrm{sm}}-46$ (where $\mathrm{Q}_{\mathrm{p}}=$ polycrystalline quartz and chert and $\mathrm{L}_{\mathrm{sm}}=$ sedimentary plus meta-sedimentary rock fragments). The shipboard data from Site 808 compare favorably with the previous results of Taira and Niitsuma (1986) for DSDP Site 582 (Fig. 3). When viewed within the conceptual framework of tectonic-provenance fields (e.g., Dickinson and Suczek, 1979; Dickinson, 1985; Valloni, 1985), most of the data from Nankai Trough plot along a mixing line between an undissected magmatic-arc component and a recycled accretionaryprism component (Marsaglia et al., in press). This type of tectonic provenance is consistent with the rock types exposed in the Izu-Honshu collision zone (Ogawa et al., 1985; Toriumi and Arai, 1989). 


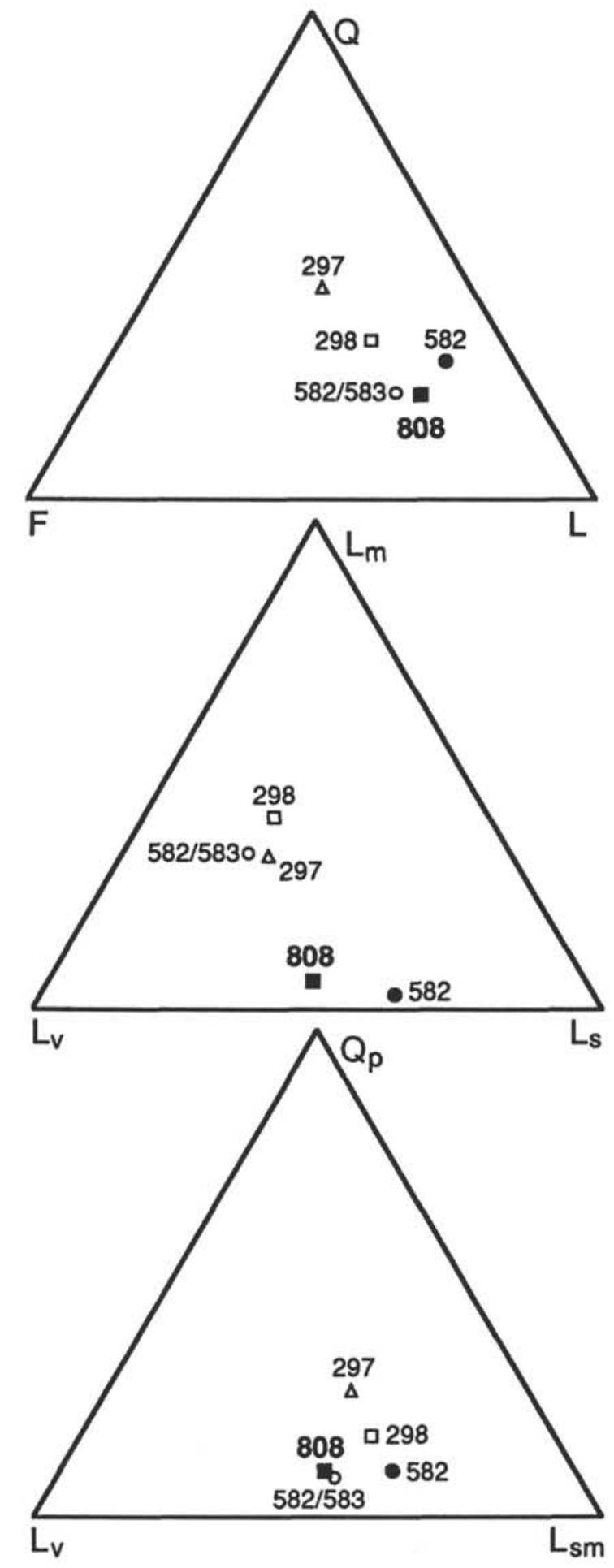

Figure 3. Summary of the results of petrographic analyses of turbidite sands deposited in the vicinity of the Nankai Trough. Symbols represent mean modal values for pertinent DSDP sites and ODP Site 808. Q = total quartz; F = plagioclase and $\mathrm{K}$-feldspar; $\mathrm{L}=$ total unstable lithic fragments; $\mathrm{L}_{\mathrm{m}}=$ finegrained metamorphic rock fragments; $\mathrm{L}_{\mathrm{v}}=$ aphanitic volcanic rock fragments; $\mathrm{L}_{\mathrm{s}}=$ fine-grained sedimentary rock fragments; $\mathrm{Q}_{\mathrm{p}}=$ polycrystalline quartz (including chert); and $\mathrm{L}_{\mathrm{sm}}=$ sedimentary and meta-sedimentary rock fragments. Sources of data for the specific sites are: Site 808, Underwood (Shipboard Scientific Party, 1991b); Site 582, Taira and Niitsuma (1986); composite of Sites 582 and 583, Marsaglia et al. (in press); Site 298, Marsaglia et al. (in press); and Site 297 (Pliocene Shikoku Basin), Marsaglia et al. (in press). For additional data, see Harrold and Moore (1975) and De Rosa et al. (1986).
Comparisons of data from Site 808 to some of the other published data sets are problematic. For example, Harrold and Moore (1975) completed Gazzi-Dickinson point counts on thin sections stained for $\mathrm{K}$-feldspar; their data show a lower content of total quartz and slightly higher percentages of sedimentary rock fragments, compared to the Site 582 data of Taira and Niitsuma (1986), who used unstained thin sections and an unspecified counting method. Recent compilations of Gazzi-Dickinson point-count data by Marsaglia et al. (in press) show similar Q-F-L modes for Sites 582 and 583, as compared to our data from Site 808 , but relatively higher percentages of metamorphic rock fragments with respect to the other polycrystalline constituents (Fig. 3). These workers, who stained their thin section for both plagioclase and $\mathrm{K}$-feldspar, also documented an apparent enrichment of metamorphic debris at Sites 297 and 298 with respect to the earlier data set of Harrold and Moore (1975). We stress here that compacted sand-sized fragments of shale grade subtly into low-grade slate and phyllite fragments; because of this, operator bias can result in pivotal changes in the $\mathrm{L}_{s} / \mathrm{L}_{\mathrm{m}}$ ratio. As a final example, the Gazzi-Dickinson analyses of thin sections by De Rosa et al. (1986) for Sites 582 and 583 yielded drastically lower values of both sedimentary and metamorphic rock fragments, compared to the data plotted on Figure 3. This enigma is difficult to explain, but differences in sample preparation (i.e., inadvertent disaggregation of fragile $\mathrm{L}_{\mathrm{sm}}$ clasts) could be responsible for the discrepancy.

Because of its internal consistency, we believe that the data set of Marsaglia et al. '(in press) is the most reliable for quantifying differences among individual drilling sites, including data from Site 808 . DSDP Site 298 displays a slight enrichment of total quartz with respect to Site 582/583 (Fig. 3). Even higher percentages of quartz are characteristic of the Pliocene turbidite sands of Shikoku Basin (Site 297), which were deposited on the opposite side of the abandoned spreading ridge with respect to Site 808. Marsaglia et al. (in press) advocate greater amounts of influx into the western part of the basin as recycled sedimentary debris eroded from exposures of the Shimanto Belt on the islands of Shikoku and Kyushu, particularly during the Pliocene. During the Holocene, the most logical transport route for this sediment in the western trench segment would be through the Ashizuri Canyon (Fig. 1). Although recycled Shimanto debris may likewise exist farther to the east at Site 808, the abundance of fresh glass shards, distinctive red pumice fragments, and many other types of volcanic debris collectively prove that the source terrane must include diverse successions of volcanic rock and active (explosive) eruptive centers. This detrital fingerprint is characteristic of the Izu-Honshu collision zone to the east.

\section{Clay Mineralogy}

Previous analyses of clay minerals in the Nankai Trough (Sites 298, 582, and 583) and Shikoku Basin (Sites 297, 442, 443, and 444) include studies by Cook et al. (1975), Chamley (1980), and Chamley et al. (1986). Cook et al. (1975) analyzed the $<2-\mu \mathrm{m}$ size fraction and used peak-intensity weighting factors relative to quartz; their analyses showed mica (illite) to be the most abundant clay mineral. Chamley (1980) based his calculations of relative mineral percentages on the respective heights of characteristic X-ray diffraction (XRD) peaks, and corrections were made through addition or subtraction of peak heights without using weighting factors. The following minerals were measured in this fashion: chlorite, smectite, kaolinite, vermiculite, palygorskite (attapulgite), and irregular mixed-layer clays. Although the clay-mineral assemblages show some diversity among locations, illite and chlorite are the most abundant minerals throughout the sampled sections of the Nankai Trough and Shikoku Basin; the previous investigators linked these minerals to sources in Japan and eastern Asia. Smectite and mixed-layer clays increase in abundance downsection, particularly within the Shikoku Basin deposits. These byproducts of volcanic activity and diagenetic alteration probably were derived from one or both of the laterally adjacent island arcs 
(Izu-Bonin to the east and Kyushu-Palau to the west), as well as from the Honshu Arc of mainland Japan. Within the Pleistocene turbidite section of the Nankai Trough, Chamley et al. (1986) documented a predominance of illite and chlorite and suggested that most of the sediments were fed axially from a source near the Izu Peninsula of central Japan.

As explained in the section on analytical methods, the values of clay-mineral percentages reported herein are based on peak areas and experimentally determined weighting factors. Because of fundamental differences in sample preparation, XRD techniques, and methods for determination of relative mineral abundances, comparisons between the data from Legs 58 and 87 and our results from Site 808 lack the desired degree of precision. Notwithstanding, at least at a reconnaissance scale, the data sets are in agreement.

\section{Inferred Dispersal Directions}

Reconstructions of sediment dispersal pathways can be unreliable if based solely on interpretations of detrital provenance, particularly in regions of geologic and bathymetric complexity such as the Nankai Trough. Several bathymetric features need to be considered in the Nankai Trough region. The northeast end of the trench is connected directly to a major sediment conduit, Suruga Trough (Le Pichon et al., 1987b; Nakamura et al., 1987). This canyon system begins near the shoreline with many small channels and slope gullies associated with the Fuji River fan-delta (Fig. 1). Three other large submarine canyons are incised into the landward trench slope (Tenryu, Shionomisaki, and Ashizuri), and these canyons might also serve as point sources of transverse influx (Fig. 1). In the easternmost part of the trench floor, the presence of an axial channel (Nankai deep-sea channel) has been documented through detailed seismic reflection surveys (Shimamura, 1989). The surface morphology of this southwest-trending channel/levee complex can be traced downgradient as far as the mouth of Shiono-misaki Canyon (Fig. 1). Fan-like sediment accumulations at the mouths of Tenryu and Shiono-misaki canyons attest to local transverse input into the trench (Le Pichon et al., 1987b; Shimamura, 1989). With the exception of Ashizuri Canyon (which is located downgradient), all of these physiographic features could provide sediment to the central trench floor in the vicinity of Site 808 .

In the western part of the Nankai Trough, the inference of southwest-flowing axial turbidity currents is supported by an analysis of the magnetic grain fabric and preferred grain orientation (Taira and Niitsuma, 1986). A modest amount of transverse influx off the lower slope also is evident from these data (Fig. 4). At Site 808, direct evidence of paleocurrent direction was obtained from measurements of dip azimuth on ripple cross-laminae within the Bouma $\mathrm{C}$-division of silty turbidites (Fig. 4). The measured turbidite beds occur within Subunit IIc of the stratigraphic section, and this lithofacies unit corresponds to the depositional environments of the outer marginal trench wedge (i.e., where the turbidite wedge laps onto the outer slope high). Unusual aspects of these turbidites include the vertical repetition of current-ripple laminae between parallel lamination, the occurrence of distinct grain-size breaks, the lack of well-developed normal size grading, variations in dip direction of cross-laminae, and weakly bioturbated caps of hemipelagic mud (Pickering et al., this volume).

True dip directions for cross-laminae within Subunit IIc were plotted after correcting for core rotation with paleomagnetic data, using the same technique as employed by shipboard structural geologists to restore deformation fabrics to their true strike and dip directions (Shipboard Scientific Party, 1991b, 1991c). These paleocurrent data are the first of their type ever obtained by DSDP/ODP. Some of the restored cross-laminae dip down the axial gradient of the trench or at an oblique angle up the seaward slope of the trench (Fig. 4). However, the majority of the azimuths are oriented toward the landward slope at high angles to the axial gradient. We believe that these results provide clear evidence for upslope movement of turbidity currents onto the seaward slope, followed by deflection or oblique reflection and back-sloshing toward the trench (Pickering et al., this volume).

Various aspects and examples of upslope turbidite deposition and flow reflection have been discussed by Pickering and Hiscott (1985), Dolan et al. (1989), Muck and Underwood (1990), and Underwood (1991). Compared to some of the more extreme cases, the seaward trench slope in the vicinity of Site 808 maintains a relatively gentle gradient of approximately $1: 150$, a width of about $10 \mathrm{~km}$, and relief (with respect to the trench axis) of only $50 \mathrm{~m}$. Izanagi side-scan sonar images (Shipboard Scientific Party, 1991a) display irregular features on the outer slope that appear to coalesce toward the trench axis (i.e., in the downslope direction); these features might represent small gullies produced by the reflected flows. It may be that some of the flows in the Nankai Trough decelerated and collapsed as they fanned out on the trench floor and moved at oblique angles up the seaward slope, following an initial stage of transport from a source in the Izu collision zone; within this scenario, the last gasp of sediment transport involved low-velocity downslope surges of suspended material perpendicular to the isobaths of the seaward slope. This type of flow trajectory has been reproduced in scaled laboratory experiments by Kneller et al. (1991). Other flows may have been deflected back toward the trench floor along a more gently curving trajectory without first losing all of their initial component of upslope-directed momentum. A final possibility to consider would be orthogonal reflection off the outer wall subsequent to transverse influx down the landward side (i.e., through the network of canyons incised into the accretionary prism). Regardless of the initial transport direction, we surmise from the theoretical and experimental results of Muck and Underwood (1990) that the turbidity currents would have to reach thicknesses of at least $33 \mathrm{~m}$ to transport sediment to an upslope elevation of $50 \mathrm{~m}$ above the trench. This humble value is much less than requirements for other sites of inferred upslope deposition, such as Tiburon Rise (Dolan et al., 1989), the Manila Trench (Damuth, 1979), and the Middle America Trench (Moore et al., 1982b).

\section{Summary}

Previously published data, as well as results from Leg 131 shipboard analyses, fail to resolve completely the respective roles of axial flows from the Izu-Honshu collision zone vs. transverse sediment influx across the width of the forearc and into the trench wedge. The through-going erosional conduits on the landward slope (e.g., Tenryu, Shiono-misaki, Ashizuri, and smaller gullies), plus fan-like sediment lobes at the canyon mouths, certainly prove that some transverse delivery does take place. Paleocurrent data suggest that axial flows predominate. These data, however, also allow for occasional lateral influx plus frequent occurrences of oblique reflection off the seaward slope (Pickering et al., this volume). Unfortunately, petrographic techniques are not sensitive enough to allow unequivocal discrimination between sand sources, particularly when data from different petrographers are compared. Given this background, we now examine the clay mineralogy of Nankai Trough sediments at Site 808 and make direct comparisons between the hemipelagic background and muds washed from the matrices of turbidite sands and turbidite silts.

\section{LABORATORY METHODS}

Methods for shipboard acquisition of bulk-powder mineralogy using XRD were published in the "Explanatory Notes" chapter of the Initial Reports volume (Shipboard Scientific Party, 1991c). These data have been supplemented with shore-based XRD analyses of clay minerals using both oriented aggregates and random-powder mounts. Routine analyses were made to determine relative percentages of three dominant clay minerals: smectite, illite, and chlorite. No chemical pretreatments were employed for these routine runs. We also measured illite crystallinity indices, mica polytypes, and $b_{0}$ lattice dimensions for the potassic micas in an attempt to clarify the possible provenance. 

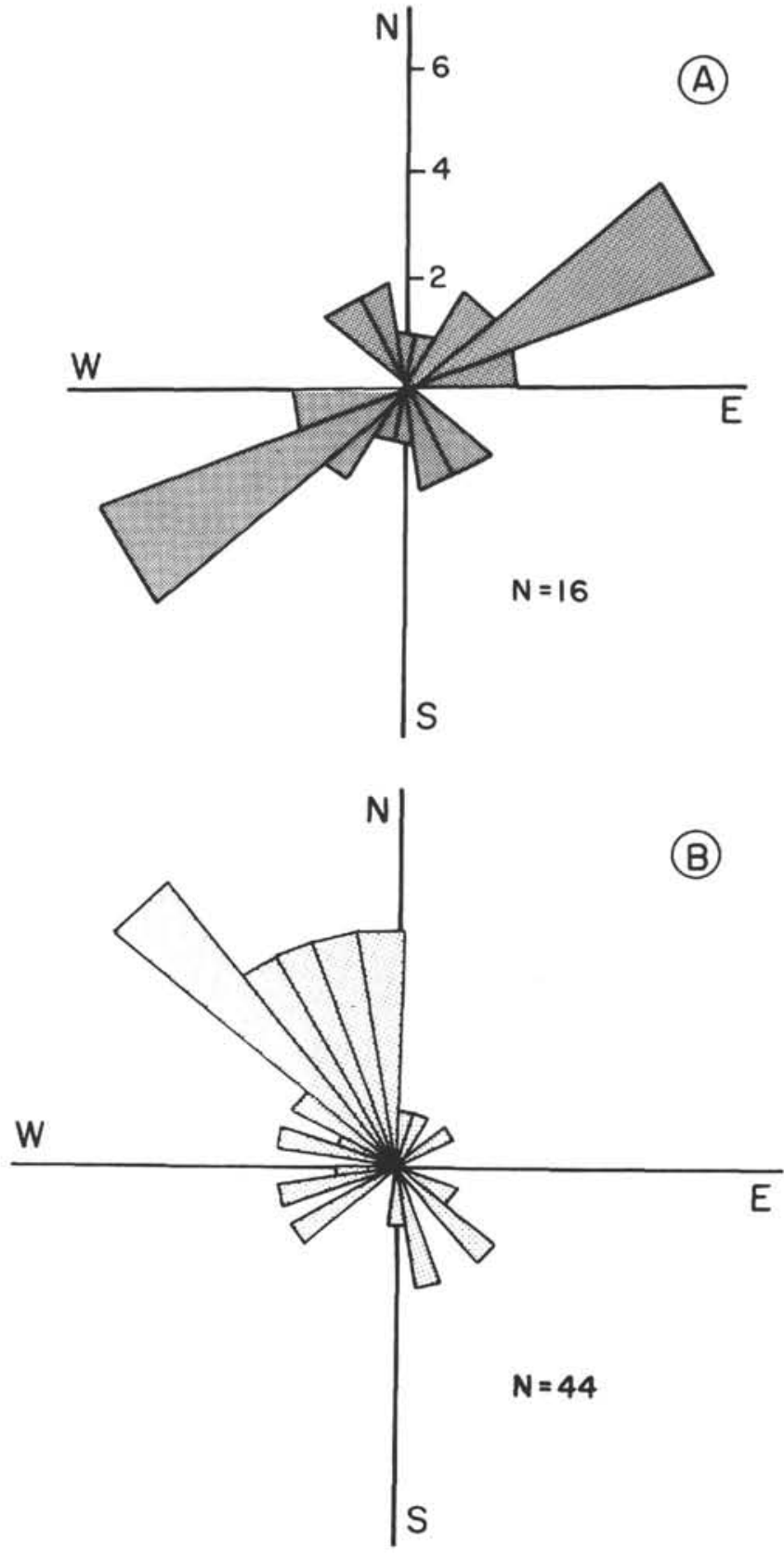

Figure 4. Paleocurrent data for turbidite deposits in the Nankai Trough. A. Mean preferred grain orientations (long axis) at DSDP Site 582, as determined by thin-section analysis; these bidirectional flow indicators correlate well with magnetic-fabric data and suggest a dominant flow toward the southwest (Taira and Niitsuma, 1986). B. Dip azimuths for ripple cross-laminae at ODP Site 808 ; these paleocurrent orientations were obtained from silty turbidites within Subunit IIc (see Fig. 2), and they have been corrected for core rotation using paleomagnetic data (Shipboard Scientific Party, 1991b). The dominant current direction is toward the north and northwest, and we believe this is a consequence of flow reflection off the seaward slope of the Nankai Trough (Pickering et al., this volume). C. Schematic relationship between radial expansion of axial turbidity currents, oblique reflection off the outer slope of the trench, and transverse influx from submarine canyons and unconfined flows moving down the landward slope.

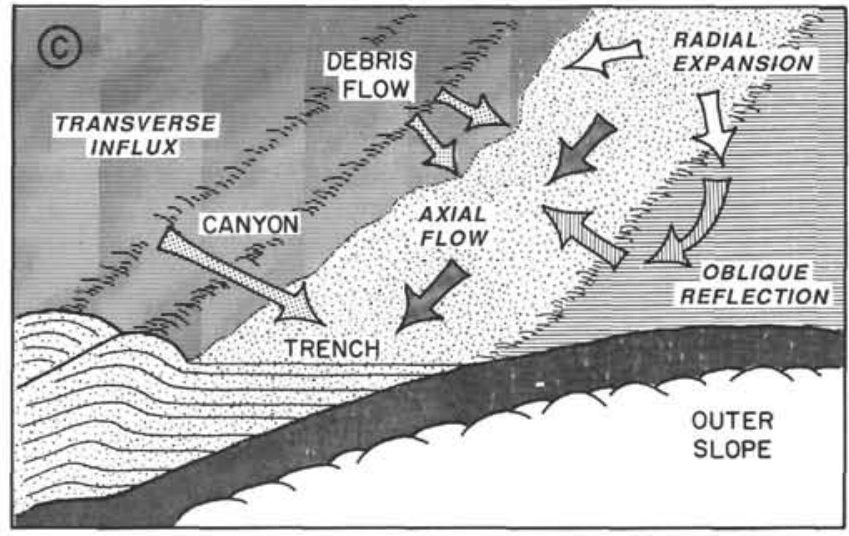

Figure 4 (continued).

All of the samples were disaggregated by gently crushing the bulk subsamples, suspending the solids in distilled/deionized water, and inserting an ultrasonic cell disrupter. Samples then were split into three size fractions using a centrifuge, with XRD analyses restricted to the $2-6-\mu \mathrm{m}$ and $<2-\mu \mathrm{m}$ size fractions. The $<6-\mu \mathrm{m}$ split was made by centrifuging the suspensions for $2.3 \mathrm{~min}$ at $300 \mathrm{rpm}$; the $2-\mu \mathrm{m}$ split required $750 \mathrm{rpm}$ for $3.3 \mathrm{~min}$. Oriented clay aggregates were prepared using the filter-peel-transfer method (Drever, 1973). A vacuum-filtration system was used to trap solid particles in $0.8-\mu \mathrm{m}$ pore, $25-\mathrm{mm}$ Gelman filters, and the clay cakes then were peeled off onto round glass slides. Measurements of mica polytypes and $b_{0}$ lattice spacing were made after boiling the respective size fractions in a solution of $2 \mathrm{~N} \mathrm{HCl}$ for $30 \mathrm{~min}$. This was done to minimize peak interference by biotite and chlorite. After washing out the acid residues, the remaining solids were dried in an oven, gently crushed, and placed into round aluminum holders. Prior to XRD analysis, both the oriented aggregates and random powders were saturated with ethylene glycol by placing the specimens in a closed glass chamber for at least $18 \mathrm{hr}$ at a temperature of approximately $60^{\circ} \mathrm{C}$.

\section{X-ray Diffraction}

All of the XRD analyses at the University of Missouri were completed using a fully automated Scintag PAD V digital system interfaced with a Microvax 2000 microprocessor. Scanning parameters for routine assessment of clay-mineral abundances were set as follows: range $=2-22^{\circ} 2 \theta$; rate $=2^{\circ} 2 \theta / \mathrm{min}$; voltage $=40 \mathrm{kV}$ and $30 \mathrm{~mA}$; radiation $=\mathrm{Cu}_{\mathrm{K} \alpha} ;$ scan $=$ fast $/$ continuous; chopper increment $($ step $)=0.03^{\circ} ;$ spinner $=$ off. Analyses of mica polytypes followed the same procedure, except that the scan range was set at $28^{\circ}-45^{\circ} 2 \theta$ and the rate slowed to $1^{\circ} 2 \theta / \mathrm{min}$. Measurements of mica $b_{0}$ spacing utilized a scanning range of $59^{\circ}-63^{\circ} 2 \theta$ and a rate of $1^{\circ} 2 \theta / \mathrm{min}$. Digital output was processed through a background correction and a deconvolution program designed to fit the resulting peaks to models, based on a Split Pearson VII profile shape (Gaussian-Lorentzian hybrid). Computer calculations of peak position $\left({ }^{\circ} 2 \theta\right)$, d-spacing $(\AA)$, width at half-height $\left(\Delta^{\circ} 2 \theta\right)$, intensity (counts/min), and integrated peak area (total counts) were made after the deconvolution subroutine. The reflections used for calculations of relative mineral abundances are: smectite (001) at a d-spacing of approximately $17 \AA$; illite (001) at approximately $10 \AA$; chlorite $(002)$ at roughly $7 \AA$. As explained below (in the section on error analysis), weighting factors were applied to the three values of integrated peak area, and the sum total was set at $100 \%$.

It is well established that the width of the illite (001) peak (with a d-spacing of about $10 \AA$ ) narrows as a function of increasing thermal alteration of the host rock (Kisch, 1987; Blenkinsop, 1988). Several variables, in addition to temperature, are known to affect illite crystallinity, including fluid pressure, pore-fluid chemistry, rates of fluid 
movement, stress, bulk-rock composition, crystal chemistry of precursor minerals, organic carbon content, heating time, and analytical technique (Frey, 1987; Kisch and Frey, 1987; Kisch, 1990; Robinson et al., 1990). As a means of specifying gross metamorphic conditions within detrital sources terranes, we obtained values of illite crystallinity index (CI) from the computed values of the glycolated peak width at half-height $\left(\Delta^{\circ} 2 \theta\right.$ ). By general consensus (for the $<2-\mu \mathrm{m}$ size fraction only), the boundary between advanced diagenesis and incipient greenschist-facies metamorphism (anchizone) corresponds to a Cl value of $0.42 \Delta^{\circ} 2 \theta$, whereas the lower limit of epimetamorphism (epizone) is set at $0.25 \Delta^{\circ} 2 \theta$ (Blenkinsop, 1988; Kisch, 1990; Robinson et al., 1990). The lower and upper temperature limits for the anchizone are approximately $200^{\circ} \mathrm{C}$ and $300^{\circ} \mathrm{C}$, respectively (Kisch, 1987).

A second mineralogic response to increasing burial temperature and pressure is the transformation of metastable $1 \mathrm{M} d$ (disordered monoclinic) illite to the $1 \mathrm{M}$ (one ordered monoclinic layer) and the $2 \mathrm{M}_{1}$ (two dioctahedral layers with an overall monoclinic symmetry) structural forms (Yoder and Eugster, 1955; Frey, 1987). Weaver and Broekstra (1984) characterized the diagenetic zone by the absence of the $2 \mathrm{M}_{1}$ polytype. The first appearance of $2 \mathrm{M}_{1}$ mica corresponds to anchimetamorphic conditions, and beyond the epizone boundary, all of the micas should be of the $2 \mathrm{M}_{1}$ variety. The interpretation of diffraction patterns for these polytypes is difficult, however, because the disordered $1 \mathrm{M} d$ polytype does not produce any diagnostic peaks and other minerals (such as quartz and feldspar) interfere with some of the diagnostic $1 \mathrm{M}$ and $2 \mathrm{M}_{1}$ peaks. We utilized the intensities of the following reflections to estimate relative abundances of the mica polytypes: $1 \mathrm{M}(112)$ reflection at a d-spacing of $3.07 \AA ; 2 \mathrm{M}_{1}(11[6])$ reflection at $2.80 \AA ; 1 \mathrm{M} d(13[3])+1 \mathrm{M}(13[3])$ composite at 2.156 $\AA$; and the composite peak at a d-spacing of $2.58 \AA$ produced by $2 \mathrm{M}_{1}$ (13[1]), (116), and (20[2]) reflections + 1Md (130) + 1M (13[1]) and (130) reflections. The percentage of $2 \mathrm{M}$ dioctahedral mica (with respect to the composite at $2.58 \AA$ ) was calculated from the intensity (I) ratio $\mathrm{I}(2.80 \AA) \div \mathrm{I}(2.58 \AA)$ and the empirical determinative curve of Maxwell and Hower (1967). As suggested by Moore and Reynolds (1989) we also calculated the following quotient of peak intensities to determine $1 \mathrm{M}: 1 \mathrm{M} d$ content: $\mathrm{Q} 1 \mathrm{M}=\mathrm{I}(3.07 \AA) \div[2.5 \times \mathrm{I}(2.156 \AA)]$. The respective percentages of $1 \mathrm{M}$ and $1 \mathrm{M} d$ (with respect to the composite total) then were obtained by multiplying the Q1M quotien by the remainder of $\left(100-\% 2 \mathrm{M}_{1}\right)$.

The $b_{0}$ unit cell dimension of potassic white mica expands when iron and magnesium cations replace octahedral alumina in the crystal lattice; as the amount of cation substitution (i.e., the celadonite content) increases, the micas become more phengitic (Velde, 1965). Although phengitic substitution is governed by several variables (temperature, pressure, oxygen fugacity, bulk-rock composition), the $b_{0}$ value is generally regarded as a measure of burial pressure where the other variables are held relatively uniform (Sassi and Scolari, 1974; Guidotti and Sassi, 1976; Padan et al., 1982). Guidotti and Sassi (1986) established the following empirical boundaries for metamorphic facies at temperatures above about $300^{\circ} \mathrm{C}: \mathrm{b}_{\mathrm{o}}<9.000 \AA=$ low-pressure facies series; $9.000 \AA<b_{0}<9.040 \AA$ = intermediatepressure facies series; $b_{0}>9.040 \AA=$ high-pressure facies series. In our study, the dimension of the $b_{0}$ cell was calculated from the corrected d-spacing of the dioctahedral $(060)$ peak, using randompowder mounts. The quartz (211) reflection (d-spacing $=1.5418 \AA$ ) was employed as an internal standard to eliminate the effects of instrument drift and errors caused by changes in alignment of the sample holder.

\section{Error Analysis}

Small amounts of kaolinite have been detected in muds from the Nankai Trough and Shikoku Basin by previous workers (Chamley, 1980; Chamley et al., 1986). The problem with quantifying kaolinite content using our analytical methods is that the chlorite $(002)$ reflection (d-spacing $=7.1 \AA$ ) interferes with the kaolinite $(001)$ reflection.
Numerous chemical and heating treatments have been developed to distinguish between these two minerals (Biscaye, 1964; Calvert, 1984; Starkey et al., 1984; Moore and Reynolds, 1989). We followed the procedure of Starkey et al. (1984), in which samples are boiled in $2 \mathrm{~N} \mathrm{HCl}$ for $30 \mathrm{~min}$, because the same treatment was required for analyses of mica polytypes. The application of $\mathrm{HCl}$ should remove any chlorite in the specimen and leave the kaolinite intact. For every sample analyzed in this manner, the 7.1- $\AA$ glycolated peak after boiling was reduced to the level of background noise. We conclude, therefore, that any kaolinite present makes up less than $5 \%$ of the sample. Other possible sources of error include interference between the chlorite and vermiculite $(002)$ reflections and expansion of the 10 - $\AA$ peak caused by a merger of the ordered mixed-layer illite/smectite peak and the discrete illite peak (Wilson, 1987; Moore and Reynolds, 1989).

Perhaps the biggest problems associated with the quantification of clay-mineral abundance is the choice of weighting factors for peak intensities and/or peak areas (Wilson, 1987). One set of weighting factors was popularized by Biscaye (1965), who based his results largely on the work of Johns et al. (1954). According to Biscaye (1965), the peak area of illite must be multiplied by $4 \times$ to normalize its value to that of an equal amount of smectite (weighting factor $=1 \times$ ); the peak-area weighting factor for chlorite is $2 \times$ (relative to smectite). Other techniques have been proposed, such as adding a pure compound like corundum as an internal flushing agent or assigning intensity factors relative to a natural quartz standard (Chung, 1974; Heath and Pisias, 1979).

Many of the published data sets for marine sediments are based on the Biscaye weighting factors (e.g., Griffin et al., 1968; Hein et al., 1976; Scholl et al., 1977; Naidu and Mowatt, 1983; Tribble, 1990; Hathon and Underwood, 1991), so we made the same types of calculations of relative mineral abundance to facilitate easy comparison with other results. As a test of accuracy, we also analyzed experimental mixtures of known weight percentages using various combinations of smectite, illite, and chlorite obtained from the Clay Mineral Society repository at the University of Missouri. The difference between calculated percentages (using Biscaye weighting factors) and the measured weight percentages serves as a measure of error (Fig. 5). We found that using a weighting factor of $4 \times$ for illite yields results that are consistently too low, and the estimates for percentage of chlorite are consistently too high using a factor of $2 \times$. The error also varies as a function of the absolute amount of each mineral present. For example, the maximum error for illite (approximately $20 \%$ less than the measured value) occurs at illite weight percentages of about $40 \%$ (Fig. 5).

One cumbersome method of error reduction is to refine the weighting factors through algebraic solutions for each experimental run. This is achieved by calculating the weighting factor required to match the XRD data for each mineral mixture to the known weight percentages. Naturally, this approach yields different values for each individual experimental test. Another problem that we encountered is the inability of the XRD system to detect illite above background noise at weight percentages of $10 \%$ and less. Additional work is in progress to solve for the effect of absolute mineral abundance on the values of each weighting factor. With these caveats in mind, the statistical averages for 16 experimental combinations (including those with low illite $w t \%$ ) are: illite $=8 \times$; chlorite $=1.8 \times$; and smectite $=1 \times$. Figure 5 shows that the error window collapses to levels that are generally below $5 \%$ with the new weighting factors. At absolute weight percentages greater than $40 \%$, the new weighting factors yield values for percentage of illite that are slightly too high. With low to moderate amounts of chlorite and smectite, there are no systematic (positive or negative) errors using the new weighting factors.

Previous investigations of illite crystallinity show that the standard deviation for duplicate runs is equal to $0.014 \Delta^{\circ} 2 \theta$ (Underwood et al., in press). Determining the accuracy of these XRD results is impeded by differences in sample preparation, grain-size distribution, machine 
setting, and analytical sensitivity (Kisch and Frey, 1987; Kisch, 1990; Robinson et al., 1990). Moreover, in the case of detrital illite populations, the $10-\AA$ peak is really a composite response to a potentially diverse mixture of particles derived from many different parent rocks, including ordered interlayers of illite/smectite. Consequently, in the case of Nankai detrital constituents, we believe that any interpretation of results beyond intervals of $0.10 \Delta^{\circ} 2 \theta$ would be misguided.

Rigorous error analysis was not attempted for determinations of mica polytypes, but the error is probably greater than $10 \%$, particularly when dealing with low intensity peaks. Past studies of mica $b_{o}$ lattice dimensions yielded a standard deviation for duplicate runs equal to $0.002 \AA$ (Underwood et al., in press). Errors in measurement of single crystals can be significant, so most interpretations of these data are based on cumulative-frequency diagrams or histograms (Naef and Stern, 1982). The biggest problem with applying this method to detrital micas is the potential for generation of a broad composite peak with interference among multiple populations. In essence, the values reported herein should be regarded as modes or averages for the detrital composite. Much as with illite CI values, we believe that the results should be used only to identify broad categories of metamorphic conditions in the source area (i.e., low-pressure, intermediate-pressure, and high-pressure facies series).

\section{RESULTS}

Any interpretation of sediment provenance based upon clay-mineral abundances must be placed within the context of the bulk mineralogy of the analyzed specimens. Shipboard XRD analyses demonstrated that hemipelagic muds and interbedded turbidite deposits in the Nankai Trough are enriched in detrital quartz and feldspar (Fig. 6). Plagioclase content is greatest within the uppermost $100 \mathrm{~m}$ of the stratigraphic column, where sandy turbidites are dominant. Plagioclase is a common monocrystalline phase, as well as a constituent of volcanic rock fragments within the turbidites. Relative percentages of total clay minerals generally amount to about $20 \%$ or less (Fig. 6).

The relative percentages displayed in Figure 6 do not take into account common amorphous constituents such as biogenic silica and volcanic glass. Cook et al. (1975) showed that many specimens from DSDP Sites 297 and 298 contain greater than $50 \%$ amorphous material, but they also calculated relative percentages of crystalline phases that are similar to those documented for Site 808. Our X-ray diffraction data, moreover, are consistent with shipboard smear-slide descriptions and grain-size analyses, in that most of the muds are classified as clayey silts with polymictic compositions (Shipboard Scientific Party, 1991b). Previous analyses of major element geochemistry at Sites 582 and 583 provide another line of evidence in support of the abundance of detrital quartz and feldspar (Minai et al., 1986). Silica concentrations, for example, are significantly greater than expected based on the biogenic content estimated by smear-slide observation and thin-section point counts; the nonbiogenic contribution of silica must be in the form of silt-sized detrital quartz.

The relative percentages of smectite, illite, and chlorite for the entire stratigraphic column at Site 808 are shown in Figure 7. No discrimination is made in Figure 7 between hemipelagic muds and clay minerals washed from the matrix of turbidite sands and silts; moreover, the data pertain only to the $<2-\mu \mathrm{m}$ size fraction, and the values are based on the new weighting factors for integrated peak area. Comparable values derived from Biscaye weighting factors are listed in Tables 1 and 2. Illite is the most abundant clay mineral throughout the section, regardless of the choice of weighting factors, the type of host sediment, or the grain-size fraction. Smectite content increases steadily downsection beginning with Unit III (trench-to-basin transition), and significant increases in smectite occur in Subunit IVa (upper Shikoku Basin facies). Both of these facies units contain numerous discrete layers of volcanic ash and tuff(Shipboard Scientific Party, 1991b), so the documented changes in clay mineralogy are probably a response to diagenetic alteration of disseminated volcanic glass (see also Masuda et al., this volume; Underwood et al., this volume). Furthermore, the increase in authigenic smectite coincides with the occurrence of the zeolite mineral clinoptilolite, which is also a replacement product of siliceous volcanic glass (Shipboard Scientific Party, 1991b). Reductions in smectite below about $820 \mathrm{mbsf}$ probably are a consequence of a reduced influx of detrital volcaniclastic constituents, as shown by the rare occurrence of ash/tuff layers within Subunit IVb. In addition, much of the discrete smectite has been lost through progressive diagenetic illitization and the formation of illite/smectite mixed-layer phases (Underwood et al., this volume). Spikes in smectite within Unit V are products of diagenetic alteration of the rhyolitic volcaniclastic deposits that characterize the base of the sedimentary section (Masuda et al., this volume).

Comparisons between the $<2-\mu \mathrm{m}$ and the $2-6-\mu \mathrm{m}$ size fractions show a modest amount of selective partitioning of clay minerals as a function of grain size. Within the hemipelagic muds, the most obvious difference is a consistent enrichment of chlorite within the larger size fraction; conversely, smectite content increases in the $<2-\mu \mathrm{m}$ fraction, particularly at depths below $480 \mathrm{mbsf}$ (Fig. 8). Illite is selectively concentrated in the finer fraction within the upper $100 \mathrm{~m}$ but does not vary much below that depth. The same grain-size partitioning is evident in clay minerals extracted from turbidite matrix (Fig. 9), except that illite partitioning is more consistent throughout the column.

Figure 10 shows a comparison among percentages of smectite, illite, chlorite, and the type of host sediment. With few exceptions, there are only minor differences in clay mineralogy between interbeds of turbidite sand/silt and the background lithology of hemipelagic mud. These differences are not systematic with respect to the host lithology and they fall within the limits of the analytical error $( \pm 5 \%)$. We conclude, therefore, that the turbidites and hemipelagites contain the same population of clay minerals eroded from source rocks in the Japanese Islands.

Because detrital illites are the dominant clay species within both hemipelagic and turbidite deposits, further refinements in the identification of detrital provenance might be possible through detailed characterization of these minerals. For example, the illite crystallinity index provides a means of assessing the grade of advanced diagenesis or metamorphism within the source area. Figure 11 shows that most CI values for the Nankai Trough sediments $(<2-\mu \mathrm{m}$ size fraction only) fall within the confines of the zone of anchimetamorphism, with some data points crossing over into the epizone (lower greenschist-facies metamorphism). Although the width of the $10-\AA$ illite peak is a composite response to a mixed detrital population, illite derived from relatively high-grade source rocks clearly dominates. Similarly, estimates of relative percentages of mica polytypes show that the $2 \mathrm{M}_{1}$ variety is the most abundant regardless of the type of host sediment or the grain-size fraction (Fig. 12). Furthermore, some of the specimens did not produce any detectable peaks associated with the $1 \mathrm{M}$ or $1 \mathrm{M} d$ mica polytypes. The coexistence of all three polytypes is consistent with anchimetamorphic conditions, and the dominance of the $2 \mathrm{M}_{1}$ form is in accord with lower greenschist-facies metamorphism. Finally, measurements of $b_{0}$ lattice spacing are between $9.014 \AA$ and $9.025 \AA$; these results demonstrate that metamorphism within the source terrane occurred under a P-T gradient of intermediate pressure (Fig. 13).

\section{DISCUSSION}

The stratigraphic uniformity and close correspondence between the respective clay mineralogies of hemipelagic muds and turbidite matrix in the Nankai Trough may not be surprising. On the other hand, the background fallout of suspended sediment does not always mimic the sediment provenance of interlayered turbidites (e.g., compare Underwood, 1986, 1991; and Hathon and Underwood, 1991). Repeated episodes of mud resuspension and mineral homogenization are common within the bottom nepheloid layer in response to bioturbation, thermohaline bottom currents, and turbidity currents. In contrast, turbidite deposits are more likely to show irregular variations and/or extreme spikes in detrital sand modes, particularly if derived from 


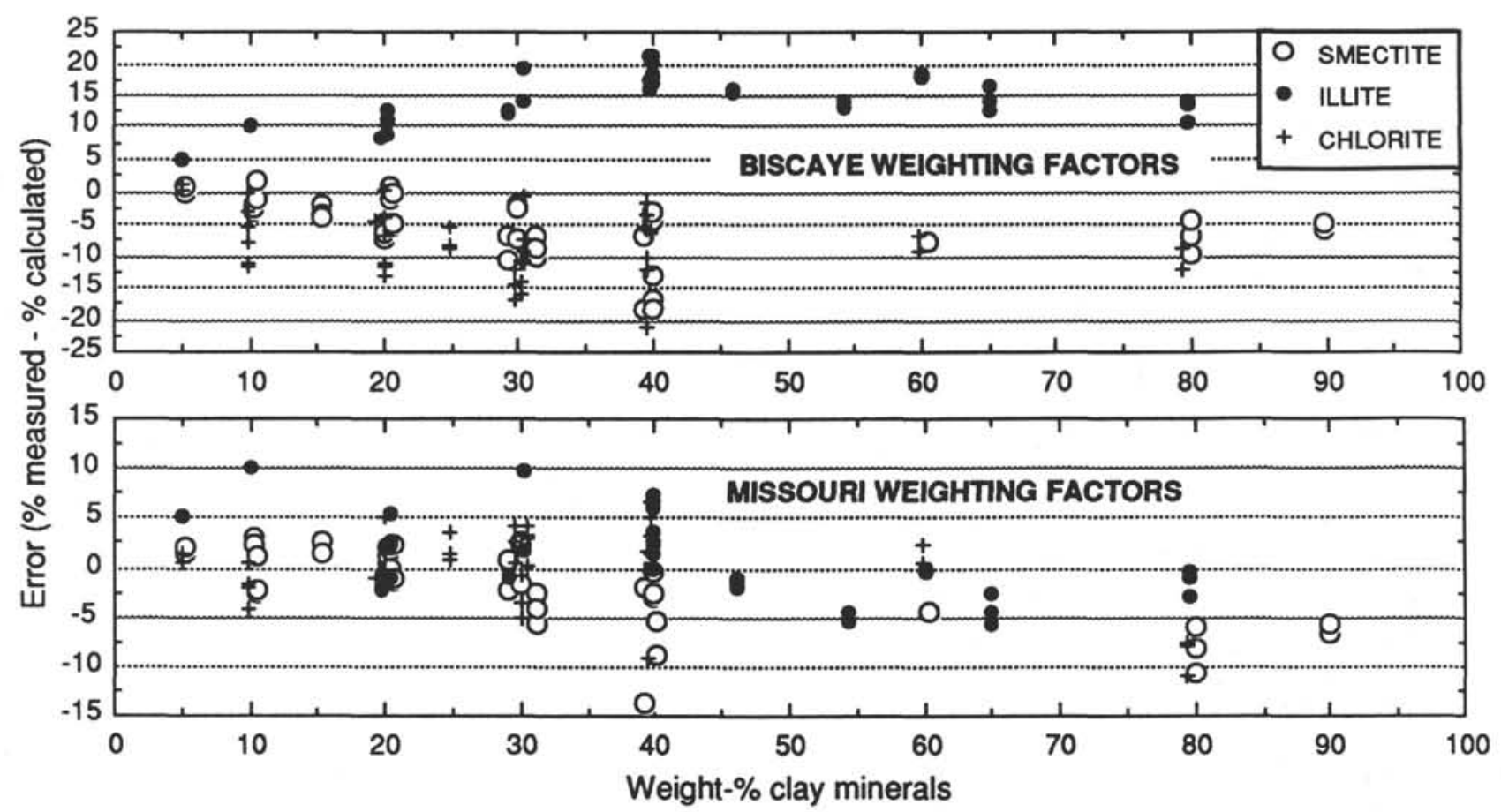

Figure 5. Results of error analysis for estimates of relative percentages of clay minerals at Site 808 . The upper diagram shows the difference between calculated percentages (using Biscaye's 1965 weighting factors) and measured weight percentages for experimental mixtures of illite, chlorite, and smectite. For example, an error of +15 for illite indicates that the Biscaye weighting factor for the 10 - $\AA$ peak area underestimates the absolute amount of that mineral by $15 \mathrm{wt} \%$ relative to the measured weight percentage of that mineral in a known three-component mixture. The lower diagram (note scale change) shows a significant collapse of the error using average weighting factors derived from algebraic solutions for each experimental run. The revised (University of Missouri) weighting factors for integrated peak area are: smectite $(17-\AA$ peak $)=1.0 \times$; chlorite $(7-\AA$ peak $)=1.8 \times$; and illite $(10-\AA$ peak $)=8.0 \times$.

multiple and diverse sources (e.g., Underwood and Norville, 1986). The uniform nature of the clay minerals in the Nankai Trough leads us to believe that a single source region has been dominant throughout the accumulation of the turbidite wedge cored at Site 808. Moreover, we conclude that the clay minerals within the matrix of turbidites came from the same basic source as the clay minerals within hemipelagic muds. Although this mineralogic match could be caused by clay infiltration following deposition of the coarser grained sand layers, the infiltration mechanism seems less plausible for layers of turbidite silt with lower permeabilities. Thus, the turbiditic clay minerals probably occupied interstitial spaces in the suspended cloud during the stages of transport, gravitational collapse, and deposition.

Past investigations of sediment provenance within the Nankai Trough and adjacent portions of Shikoku Basin have led most workers to the conclusion that the dominant sediment source area is located in the collision zone between the Izu-Bonin Arc and the Honshu Arc. The Fuji River drainage network carries detritus from this region into the head of the Suruga Trough, which, in turn, is connected to the eastern edge of Nankai Trough (Fig. 14). Most of the sediment within the Nankai trench wedge flows down the axial gradient toward the southwest. During Leg 131, shipboard petrographic analyses of turbidite sands (Fig. 3) and bulk powder XRD data (Fig. 6) provided additional evidence in favor of this interpretation, although results were not detailed or precise enough to be definitive. Shore-based XRD analyses of clay minerals demonstrate that the Nankai Trough sediments contain abundant detrital illite derived from a source terrane that has been exposed to conditions of anchimetamorphism, grading into lower greenschist-facies alteration. Based upon the low phengite content of the detrital micas, the P-T gradient within the source region must have been within the limits of the low-pressure facies series of metamorphism. The $b_{0}$ values are similar to those documented in mountain belts such as the Alps and the Caledonides (Sassi and Scolari, 1974; Padan et al., 1982).
The geology of the Izu-Honshu collision zone (Fig. 14) has been summarized by Ogawa et al. (1985), Ogawa and Taniguchi (1988), Toriumi and Arai (1989), and Soh et al. (1991). The lithologies are diverse and include the following fundamental units: accreted sedimentary and volcanic rocks of the Shimanto Belt; ophiolitic rocks of early Tertiary age; Neogene sedimentary rocks composed of finegrained tuffaceous and terrigenous debris; quartz diorite bodies that intrude the Miocene volcaniclastic units; and Quaternary volcanic centers (including Mt. Fuji). The grades of burial metamorphism within the collision zone range from the zeolite facies to the prehnitepumpellyite facies and the actinolite-greenschist facies (Toriumi and Arai, 1989). Superimposed on the regional pattern of burial metamorphism are zones of contact metamorphism associated with the Miocene intrusions; metamorphic grades within the contact aureoles are as high as amphibolite facies (Toriumi and Arai, 1989). These conditions of regional and contact metamorphism are consistent with the high percentages of detrital illite (and subordinate chlorite) in the Nankai sediments, the low phengite content of detrital micas, the dominance of the $2 \mathrm{M}_{1}$ mica polytype, and the documented values of illite crystallinity. Furthermore, if one also considers the sand-sized turbidite fraction, the Izu-Honshu collision zone provides a source for both neovolcanic and paleovolcanic rock fragments, recycled sedimentary and low-grade metasedimentary rock fragments, monocrystalline feldspar, and abundant quartz.

Figure 14 shows that the Shimanto Belt extends across most of southwest Japan, with important exposures on the Kii Peninsula of Honshu, southern Shikoku, and southern Kyushu (Taira et al., 1982; 1988; Kumon et al., 1988; Nishi, 1988). The metamorphic grade within the Shimanto Belt ranges from the zeolite facies through the prehnite-pumpellyite facies and into the lower greenschist facies (Toriumi and Teruya, 1988). Thus, these accreted rocks could provide a logical source for some of the detritus in Nankai Trough along its entire length. In addition, the Shimanto strata were affected by anoma- 


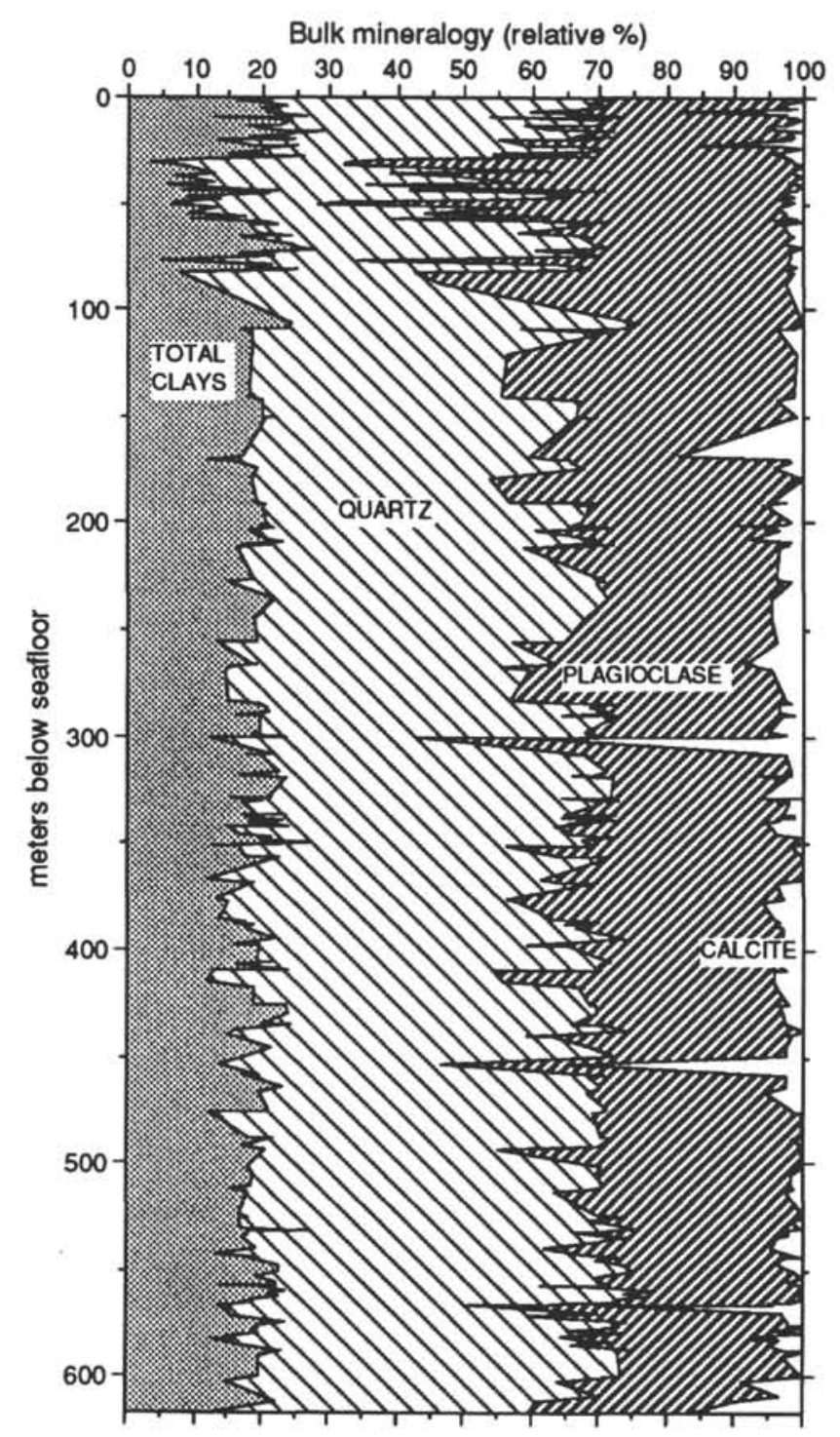

Figure 6. Results of shipboard X-ray diffraction analyses of random bulk powders, Site 808, Units I, II, and III. Relative mineral percentages (from Shipboard Scientific Party, 1991b) are based on weighted peak intensities (normalized to the quartz peak at $26.65^{\circ} \theta$ ) and generally show that the clay minerals (smectite, illite, kaolinite, and chlorite) total $20 \%$ or less with respect to the sum of quartz, plagioclase, calcite, and clay minerals. Because amorphous phases (e.g., volcanic glass and biogenic silica) were not detected during the shipboard analyses, the absolute error in these estimates could be significant.

lous near-trench acidic volcanic activity, granitic intrusions, and local intrusions of mafic rock during the middle Miocene (Oba, 1977; Miyake, 1985; Terakado et al., 1988; Hibbard and Karig, 1990).

We acknowledge that sediment recycling from the Shimanto Belt may be important locally, but four lines of evidence lead us to suggest that the potential source areas on the Kii Peninsula and Shikoku have played minor roles in the regional sediment budget of the Nankai Trough. First, we would expect the mineralogic signature of transverse influx to be most obvious within lithofacies Unit I (slope-apron deposits). Instead, the compositional uniformity between these deposits and the accreted sediments of the trench wedge support the contention of a common source. Most of the sediments of the lower slope apron probably were deposited by onlap of axial turbidity currents and their resulting clouds of suspended mud onto the toe of

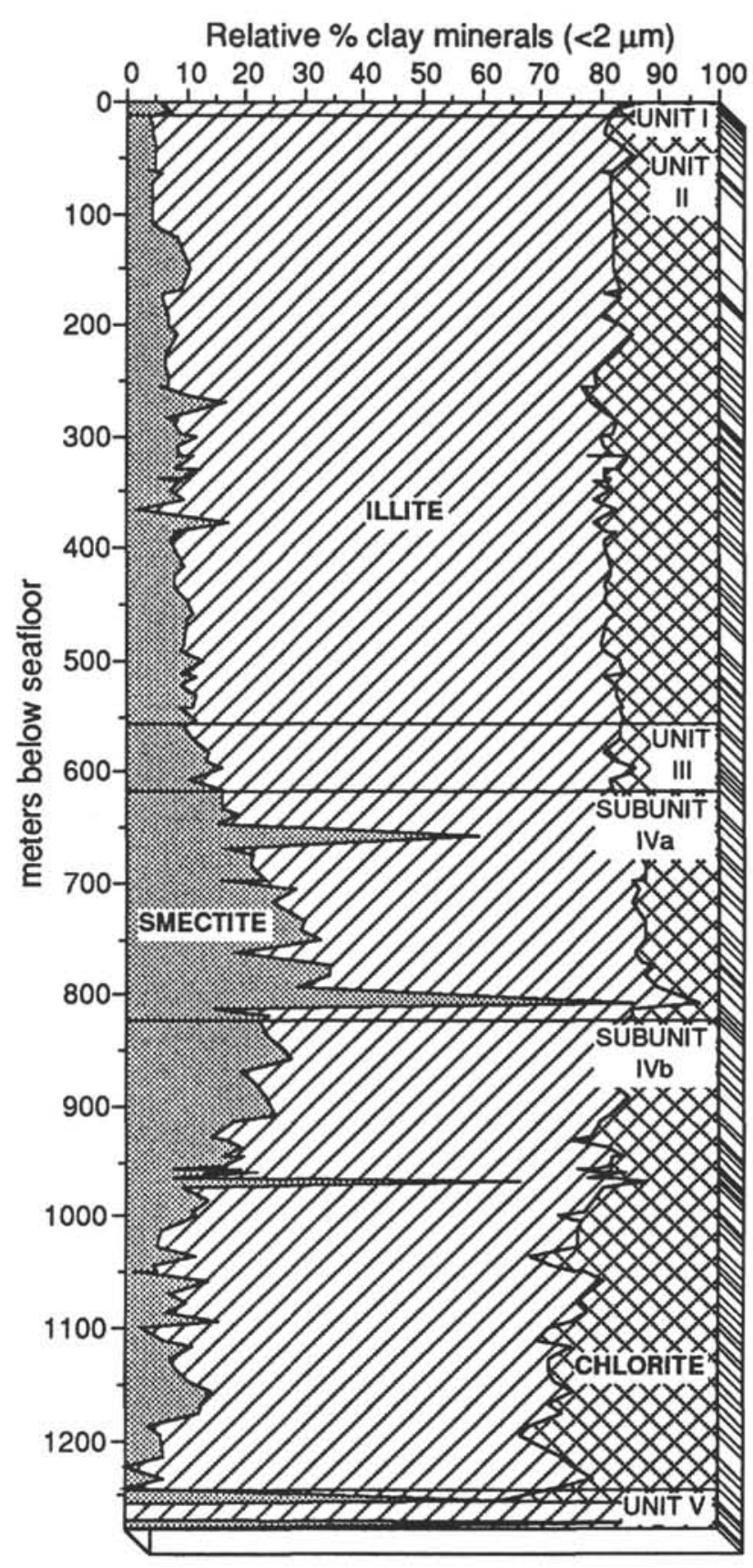

Figure 7. Relative percentages of smectite, illite, and chlorite for the $<2-\mu \mathrm{m}$ size fraction of hemipelagic muds at Site 808, based on University of Missouri peak-area weighting factors. The column on the right of the diagram shows the locations of sample control points (horizontal lines). See Table 1 for specific sample numbers, depths, integrated peak areas, clay-mineral percentages, and recalculated percentages based on the Biscaye (1965) weighting factors.

the accretionary prism. Second, unlike the Fuji and Tenryu drainage basins to the east, the potential source regions of Shikoku and the Kii Peninsula are not sites of active volcanism (Fig. 14). Thus, it is difficult to account for the documented influx of neovolcanic material in the turbidite sands. Third, the south side of the drainage divide on the island of Shikoku (as well as on the Kii Peninsula) includes high-pressure pelitic and basic schists of the Sambagawa Belt (Ernst et al., 1970; Banno, 1986; Hara et al., 1990; Higashino, 1990). Lying between the Sambagawa Belt and the Cretaceous Shimanto Belt is the Chichibu Belt (Fig. 14), which is thought to represent parts of a 
Table 1. X-ray diffraction data for hemipelagic mud samples, Nankai Trench wedge.

\begin{tabular}{|c|c|c|c|c|c|c|c|c|c|c|c|c|c|c|c|c|c|c|c|}
\hline \multirow{3}{*}{$\begin{array}{l}\text { Sample } \\
(\mathrm{cm})\end{array}$} & \multirow{3}{*}{$\begin{array}{l}\text { Depth } \\
\text { (mbsf) }\end{array}$} & \multirow{2}{*}{\multicolumn{3}{|c|}{$\frac{<2-\mu \mathrm{m} \text { size fraction }}{\text { Integrated peak area (counts) }}$}} & \multicolumn{6}{|c|}{ Estimated mineral percentage } & \multirow{2}{*}{\multicolumn{3}{|c|}{$\frac{2-6-\mu \mathrm{m} \text { size fraction }}{\text { Integrated peak area (counts) }}$}} & \multicolumn{6}{|c|}{ Estimated mineral percentage } \\
\hline & & & & & \multicolumn{3}{|c|}{ Biscaye factors } & \multicolumn{3}{|c|}{ Missouri factors } & & & & \multicolumn{3}{|c|}{ Biscaye factors } & \multicolumn{3}{|c|}{ Missouri factors } \\
\hline & & Smectite & Illite & Chlorite & $S(\%)$ & $\mathrm{I}(\%)$ & $\mathrm{C}(\%)$ & $\mathrm{S}(\%)$ & $I(\%)$ & $\mathrm{C}(\%)$ & Smectite & Illite & Chlorite & $\mathrm{S}(\%)$ & $\mathrm{I}(\%)$ & $\mathrm{C}(\%)$ & $\mathrm{S}(\%)$ & $\mathrm{I}(\%)$ & $\mathrm{C}(\%)$ \\
\hline \multicolumn{20}{|l|}{ 131-808A- } \\
\hline $1 \mathrm{H}-1,62$ & 0.62 & 7707 & 10900 & 10604 & 11 & 60 & 29 & 7 & 76 & 17 & 3076 & 4332 & 5035 & 10 & 57 & 33 & 7 & 74 & 19 \\
\hline $1 \mathrm{H}-2,15$ & 1.65 & 7286 & 12484 & 9940 & 9 & 65 & 26 & 6 & 80 & 14 & 2714 & 5476 & 5886 & 7 & 60 & 32 & 5 & 77 & 19 \\
\hline $1 \mathrm{H}-3,134$ & 4.34 & 4077 & 5712 & 5986 & 10 & 59 & 31 & 7 & 75 & 18 & 1775 & 2429 & 3256 & 10 & 54 & 36 & 7 & 72 & 22 \\
\hline $2 \mathrm{H}-1,83$ & 7.13 & 3361 & 4400 & 4504 & 11 & 59 & 30 & 7 & 75 & 17 & 1745 & 2489 & 2985 & 10 & 56 & 34 & 6 & 74 & 20 \\
\hline $2 \mathrm{H}-6,1$ & 13.80 & 3329 & 8939 & 9155 & 6 & 62 & 32 & 4 & 78 & 18 & 1934 & 4440 & 4025 & 7 & 64 & 29 & 4 & 79 & 16 \\
\hline $3 \mathrm{H}-3,97$ & 19.67 & 3402 & 7450 & 8249 & 7 & 60 & 33 & 4 & 77 & 19 & 873 & 2815 & 4459 & 4 & 53 & 42 & 3 & 72 & 26 \\
\hline $4 \mathrm{H}-2,90$ & 27.70 & 4661 & 10349 & 11722 & 7 & 60 & 34 & 4 & 76 & 19 & 1850 & 3590 & 5443 & 7 & 53 & 40 & 5 & 71 & 24 \\
\hline $5 \mathrm{H}-2,23$ & 36.53 & 3573 & 7378 & 7201 & 8 & 62 & 30 & 5 & 78 & 17 & 1979 & 3205 & 3986 & 9 & 56 & 35 & 6 & 74 & 21 \\
\hline $6 \mathrm{H}-4,45$ & 47.56 & 5196 & 11228 & 8794 & 8 & 66 & 26 & 5 & 81 & 14 & 3877 & 6674 & 8329 & 8 & 57 & 35 & 5 & 74 & 21 \\
\hline $7 \mathrm{H}-5,90$ & 60.60 & 4584 & 8872 & 9155 & 8 & 61 & 31 & 5 & 77 & 18 & 2182 & 3367 & 4994 & 9 & 53 & 39 & 6 & 71 & 24 \\
\hline $8 \mathrm{H}-1,128$ & 64.54 & 4672 & 7697 & 8230 & 9 & 59 & 32 & 6 & 76 & 18 & 1707 & 3667 & 4750 & 7 & 57 & 37 & 4 & 74 & 22 \\
\hline $9 \mathrm{H}-4,111$ & 73.91 & 4517 & 10903 & 11244 & 6 & 62 & 32 & 4 & 78 & 18 & 2083 & 4710 & 6479 & 6 & 56 & 38 & 4 & 73 & 23 \\
\hline $13 \mathrm{H}-3,66$ & 109.40 & 4120 & 9686 & 9834 & 7 & 62 & 31 & 4 & 78 & 18 & 2679 & 3320 & 4770 & 11 & 52 & 37 & 7 & 70 & 23 \\
\hline \multicolumn{20}{|l|}{ 131-808B- } \\
\hline $2 \mathrm{X}-1,44$ & 120.85 & 7223 & 8379 & 8577 & 24 & 52 & 24 & 8 & 75 & 17 & & & & & & & & & \\
\hline $2 X-1,73$ & 121.33 & 3472 & 3641 & 3965 & 13 & 56 & 31 & 9 & 73 & 18 & & & & & & & & & \\
\hline $5 X-1,55$ & 150.05 & 8306 & 7074 & 7860 & 16 & 54 & 30 & 11 & 72 & 18 & & & & & & & & & \\
\hline $7 X-1,102$ & 169.82 & 7875 & 8144 & 8156 & 14 & 57 & 29 & 9 & 74 & 17 & 2845 & 3490 & 4244 & 11 & 55 & 34 & 7 & 73 & 20 \\
\hline $7 X-2,14$ & 170.44 & 7345 & 10312 & 11938 & 10 & 57 & 33 & 7 & 74 & 19 & 2163 & 4076 & 5238 & 7 & 56 & 36 & 5 & 74 & 21 \\
\hline $7 X-4,31$ & 173.90 & 8251 & 13366 & 12622 & 12 & 58 & 30 & 6 & 78 & 16 & & & & & & & & & \\
\hline $9 X-2,62$ & 190.32 & 6974 & 8765 & 10668 & 11 & 55 & 34 & 7 & 73 & 20 & 2060 & 2817 & 4002 & 10 & 53 & 38 & 6 & 71 & 23 \\
\hline $10 \mathrm{X}-2,130$ & 200.20 & 3260 & 4585 & 4402 & 11 & 60 & 29 & 7 & 77 & 17 & & & & & & & & & \\
\hline $11 X-1,105$ & 207.85 & 3116 & 3571 & 3037 & 13 & 61 & 26 & 8 & 77 & 15 & & & & & & & & & \\
\hline $13 X-1,117$ & 226.97 & 3326 & 4769 & 4895 & 10 & 59 & 30 & 7 & 76 & 18 & 2606 & 3443 & 4535 & 10 & 54 & 36 & 7 & 72 & 21 \\
\hline $13 X-2,64$ & 227.94 & 5018 & 7363 & 7625 & 10 & 59 & 31 & 6 & 76 & 18 & & & & & & & & & \\
\hline $14 \mathrm{X}-1,52$ & 235.62 & 3355 & 4884 & 5900 & 10 & 56 & 34 & 6 & 74 & 20 & 3564 & 4802 & 6898 & 10 & 53 & 38 & 7 & 71 & 23 \\
\hline $15 X-1,21$ & 244.71 & 10382 & 13180 & 16864 & 11 & 54 & 35 & 7 & 72 & 21 & 3370 & 3686 & 5397 & 12 & 51 & 37 & 8 & 69 & 23 \\
\hline $16 \mathrm{X}-1,50$ & 254.70 & 11440 & 15466 & 19411 & 10 & 55 & 35 & 7 & 73 & 21 & 3608 & 5508 & 7416 & 9 & 54 & 37 & 6 & 72 & 22 \\
\hline $16 \mathrm{X}-1,118$ & 255.38 & 4481 & 6530 & 9429 & 9 & 53 & 38 & 6 & 71 & 23 & & & & & & & & & \\
\hline $17 X-2,45$ & 265.35 & 5262 & 4019 & 5793 & 16 & 49 & 35 & 11 & 67 & 22 & & & & & & & & & \\
\hline $17 X-4,88$ & 268.74 & 15441 & 7064 & 11045 & 23 & 43 & 34 & 17 & 62 & 22 & & & & & & & & & \\
\hline $19 \mathrm{X}-1,103$ & 283.53 & 4822 & 6324 & 6600 & 11 & 58 & 30 & 7 & 75 & 18 & 2977 & 3748 & 5158 & 11 & 53 & 36 & 7 & 71 & 22 \\
\hline 19X-CC, 10 & 286.22 & 5777 & 6324 & 6600 & 13 & 57 & 30 & 8 & 74 & 17 & 2977 & 3492 & 5032 & 11 & 52 & 37 & 7 & 70 & 23 \\
\hline $20 \mathrm{X}-1,57$ & 288.47 & 6196 & 6935 & 7232 & 13 & 57 & 30 & 8 & 74 & 17 & & & & & & & & & \\
\hline $22 \mathrm{X}-1,139$ & 308.49 & 4921 & 5130 & 6199 & 13 & 54 & 33 & 9 & 72 & 20 & & & & & & & & & \\
\hline $23 X-1,4$ & 316.84 & 10729 & 10471 & 11505 & 14 & 55 & 30 & 9 & 73 & 18 & 7279 & 7596 & 9514 & 13 & 54 & 34 & 9 & 71 & 20 \\
\hline 23X-CC, 8 & 317.37 & 8379 & 8389 & 11931 & 13 & 51 & 36 & 9 & 69 & 22 & & & & & & & & & \\
\hline $24 \mathrm{X}-3,31$ & 329.71 & 6835 & 4830 & 6004 & 18 & 51 & 31 & 12 & 69 & 19 & & & & & & & & & \\
\hline $25 \mathrm{X}-1,24$ & 336.24 & 8081 & 7295 & 8758 & 15 & 53 & 32 & 10 & 71 & 19 & 4509 & 4391 & 6426 & 13 & 50 & 37 & 9 & 69 & 23 \\
\hline $25 \mathrm{X}-2,49$ & 337.99 & 5395 & 9592 & 10282 & 8 & 60 & 32 & 5 & 76 & 18 & & & & & & & & & \\
\hline $25 \mathrm{X}-3,112$ & 340.12 & 8672 & 9595 & 10531 & 13 & 56 & 31 & 8 & 74 & 18 & & & & & & & & & \\
\hline $25 X-4,96$ & 341.46 & 6234 & 6012 & 8057 & 13 & 52 & 35 & 9 & 70 & 21 & 4657 & 3917 & 5967 & 14 & 49 & 37 & 10 & 67 & 23 \\
\hline
\end{tabular}


Table 1 (continued).

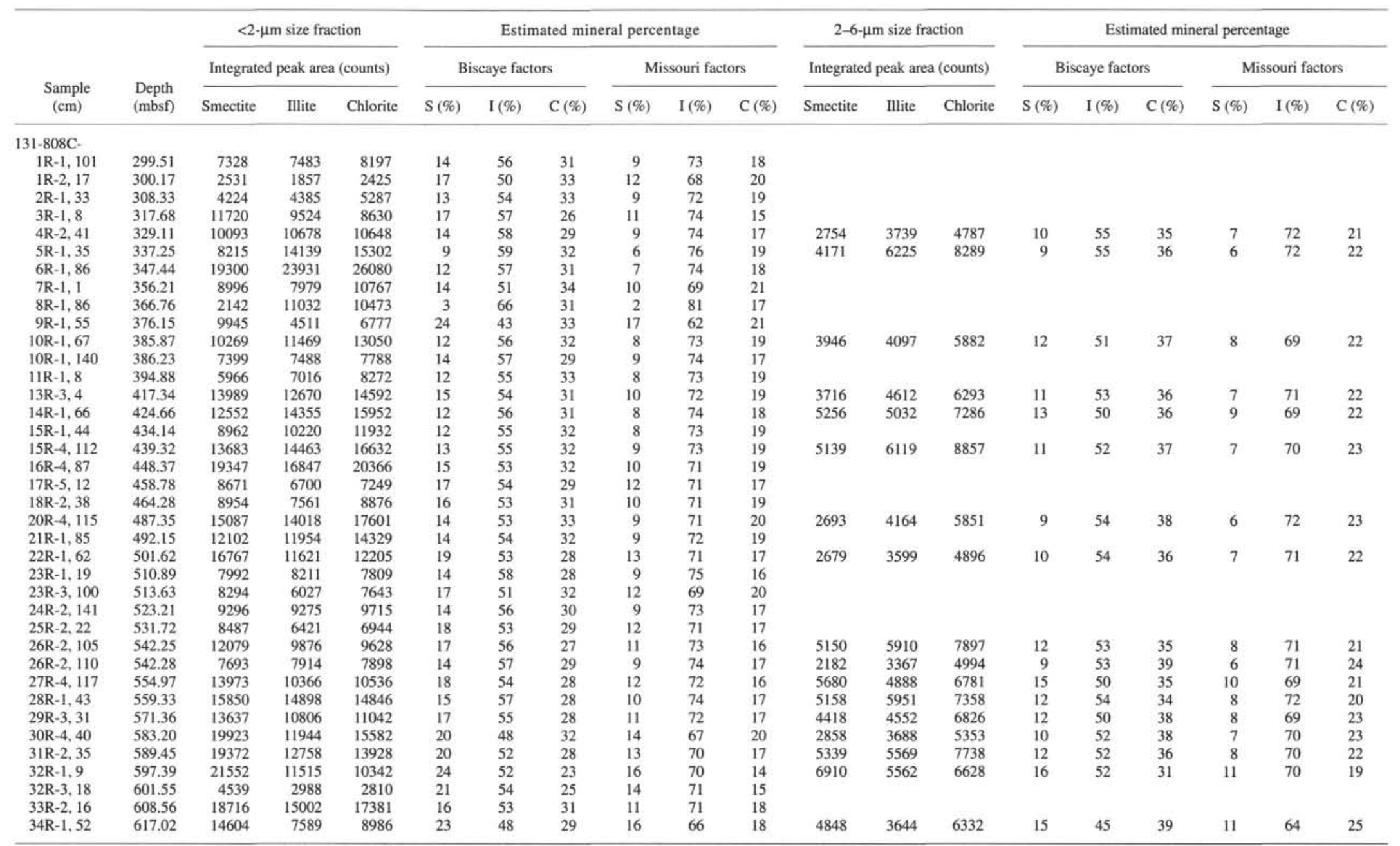


Table 2. X-ray diffraction data for turbidite matrix samples, Nankai Trench wedge.

\begin{tabular}{|c|c|c|c|c|c|c|c|c|c|c|c|c|c|c|c|c|c|c|c|}
\hline \multirow{3}{*}{$\begin{array}{l}\text { Sample } \\
(\mathrm{cm})\end{array}$} & \multirow{3}{*}{$\begin{array}{l}\text { Depth } \\
\text { (mbsf) }\end{array}$} & \multirow{2}{*}{\multicolumn{3}{|c|}{$\frac{<2-\mu \mathrm{m} \text { size fraction }}{\text { Integrated peak area (counts) }}$}} & \multicolumn{6}{|c|}{ Estimated mineral percentage } & \multirow{2}{*}{\multicolumn{3}{|c|}{$\frac{2-6-\mu \mathrm{m} \text { size fraction }}{\text { Integrated peak area (counts) }}$}} & \multicolumn{6}{|c|}{ Estimated mineral percentage } \\
\hline & & & & & \multicolumn{3}{|c|}{ Biscaye factors } & \multicolumn{3}{|c|}{ Missouri factors } & & & & \multicolumn{3}{|c|}{ Biscaye factors } & \multicolumn{3}{|c|}{ Missouri factors } \\
\hline & & Smectite & Illite & Chlorite & $\mathrm{S}(\%)$ & $1(\%)$ & $\mathrm{C}(\%)$ & $S(\%)$ & $I(\%)$ & $\mathrm{C}(\%)$ & Smectite & Illite & Chlorite & $\mathrm{S}(\%)$ & $\mathrm{I}(\%)$ & $\mathrm{C}(\%)$ & $\mathrm{S}(\%)$ & $I(\%)$ & $\mathrm{C}(\%)$ \\
\hline \multicolumn{20}{|l|}{ 131-808A- } \\
\hline $1 \mathrm{H}-3,91$ & 3.91 & 8053 & 8501 & 7864 & 14 & 59 & 27 & 9 & 75 & 16 & 2568 & 3706 & 4742 & 10 & 55 & 35 & 6 & 73 & 21 \\
\hline $1 \mathrm{H}-3,117$ & 4.17 & 4780 & 7242 & 7534 & 10 & 59 & 31 & 6 & 76 & 18 & 578 & 3162 & 4949 & 2 & 55 & 43 & 2 & 73 & 26 \\
\hline $2 \mathrm{H}-1,37$ & 6.67 & 4695 & 10102 & 8640 & 8 & 65 & 28 & 5 & 80 & 15 & 3903 & 6296 & 6924 & 9 & 59 & 32 & 6 & 75 & 19 \\
\hline $3 \mathrm{H}-4,7$ & 20.37 & 7397 & 10962 & 9325 & 11 & 63 & 27 & 7 & 78 & 15 & 4311 & 5030 & 6077 & 12 & 55 & 33 & 8 & 73 & 20 \\
\hline $3 \mathrm{H}-5,65$ & 22.45 & 4058 & 7625 & 7222 & 8 & 62 & 29 & 5 & 78 & 17 & 2153 & 6606 & 7302 & 5 & 61 & 34 & 3 & 78 & 19 \\
\hline $3 \mathrm{H}-5,74$ & 22.54 & 5561 & 9379 & 9762 & 9 & 60 & 31 & 6 & 76 & 18 & 1623 & 4240 & 5591 & 5 & 57 & 38 & 4 & 74 & 22 \\
\hline $4 \mathrm{H}-1,47$ & 25.77 & 8806 & 7571 & 6870 & 17 & 57 & 26 & 11 & 74 & 15 & 3043 & 3600 & 4708 & 11 & 54 & 35 & 8 & 71 & 21 \\
\hline $5 \mathrm{H}-4,62$ & 39.92 & 8947 & 13311 & 13550 & 10 & 60 & 30 & 6 & 76 & 17 & 2843 & 5534 & 6767 & 7 & 57 & 35 & 5 & 75 & 21 \\
\hline $6 \mathrm{H}-1,26$ & 44.56 & 9359 & 12274 & 10249 & 12 & 62 & 26 & 7 & 78 & 15 & 2127 & 4086 & 4455 & 8 & 60 & 33 & 5 & 76 & 19 \\
\hline $6 \mathrm{H}-4,59$ & 49.39 & 6073 & 9575 & 7646 & 10 & 64 & 26 & 6 & 79 & 14 & 3286 & 5037 & 5198 & 10 & 60 & 31 & 6 & 76 & 18 \\
\hline $7 \mathrm{H}-4,104$ & 59.34 & 4929 & 7043 & 6143 & 11 & 62 & 27 & 7 & 78 & 15 & 2371 & 4313 & 4395 & 8 & 61 & 31 & 5 & 77 & 18 \\
\hline $9 \mathrm{H}-1,132$ & 69.62 & 6266 & 12473 & 12359 & 8 & 62 & 31 & 5 & 78 & 17 & 2326 & 4841 & 5422 & 7 & 60 & 33 & 5 & 76 & 19 \\
\hline $9 \mathrm{H}-4,118$ & 73.98 & 10853 & 10786 & 9580 & 15 & 59 & 26 & 9 & 75 & 15 & 2650 & 3422 & 3846 & II & 57 & 32 & 7 & 74 & 19 \\
\hline $10 \mathrm{H}-4,55$ & 83.85 & 5475 & 5595 & 6032 & 14 & 56 & 30 & 9 & 73 & 18 & 2020 & 4114 & 3920 & 8 & 63 & 30 & 5 & 78 & 17 \\
\hline \multicolumn{20}{|l|}{ 131-808B- } \\
\hline $4 \mathrm{X}-1,90$ & 140.80 & 10889 & 15479 & 14916 & 11 & 60 & 29 & 7 & 77 & 17 & 3897 & 6236 & 8326 & 9 & 55 & 37 & 6 & 73 & 22 \\
\hline \multicolumn{20}{|l|}{$131-808 \mathrm{C}-$} \\
\hline $4 \mathrm{R}-2,47$ & 329.17 & 22720 & 21588 & 20994 & 15 & 57 & 28 & 10 & 74 & 16 & 3959 & 5853 & 7808 & 9 & 54 & 36 & 6 & 72 & 22 \\
\hline $8 \mathrm{R}-1,103$ & 366.93 & 22446 & 22453 & 22984 & 14 & 57 & 29 & 9 & 74 & 17 & 4101 & 7368 & 10624 & 7 & 54 & 39 & 5 & 72 & 23 \\
\hline $9 \mathrm{R}-1,24$ & 375.84 & 20231 & 11389 & 16359 & 21 & 46 & 33 & 14 & 65 & 21 & 4932 & 3767 & 5761 & 16 & 48 & 37 & 11 & 66 & 23 \\
\hline $12 \mathrm{R}-1,110$ & 405.70 & 11614 & 10122 & 11275 & 16 & 54 & 30 & 10 & 72 & 18 & 5397 & 5688 & 8106 & 12 & 51 & 37 & 8 & 69 & 22 \\
\hline $13 \mathrm{R}-2,85$ & 416.65 & 9503 & 11051 & 11945 & 12 & 57 & 31 & 8 & 74 & 18 & 2355 & 4180 & 5971 & 8 & 54 & 39 & 5 & 72 & 23 \\
\hline $14 \mathrm{R}-2,97$ & 426.47 & 19049 & 21977 & 18499 & 13 & 61 & 26 & 8 & 77 & 15 & 4370 & 4310 & 5706 & 13 & 52 & 35 & 9 & 70 & 21 \\
\hline $15 \mathrm{R}-1,85$ & 434.55 & 12474 & 12195 & 14718 & 14 & 54 & 32 & 9 & 71 & 19 & 2406 & 3960 & 6270 & 8 & 51 & 41 & 5 & 70 & 25 \\
\hline $16 \mathrm{R}-2,69$ & 445.19 & 9221 & 8120 & 7787 & 16 & 57 & 27 & 10 & 74 & 16 & 5447 & 5839 & 8033 & 12 & 52 & 36 & 8 & 70 & 22 \\
\hline $17 \mathrm{R}-2,8$ & 454.28 & 11325 & 11458 & 11080 & 14 & 58 & 28 & 9 & 75 & 16 & 2853 & 3742 & 5560 & 10 & 52 & 38 & 7 & 70 & 23 \\
\hline $19 \mathrm{R}-1,49$ & 472.49 & 11693 & 10374 & 11490 & 15 & 54 & 30 & 10 & 72 & 18 & 2405 & 2978 & 4698 & 10 & 50 & 40 & 7 & 69 & 24 \\
\hline $24 \mathrm{R}-1,55$ & 520.85 & 14449 & 12756 & 15095 & 15 & 53 & 32 & 10 & 71 & 19 & 2754 & 3511 & 5712 & 10 & 50 & 40 & 7 & 68 & 25 \\
\hline $28 \mathrm{R}-1,104$ & 559.40 & 13051 & 12447 & 15666 & 14 & 53 & 33 & 9 & 71 & 20 & 5100 & 5864 & 9397 & 11 & 50 & 40 & 7 & 68 & 25 \\
\hline
\end{tabular}




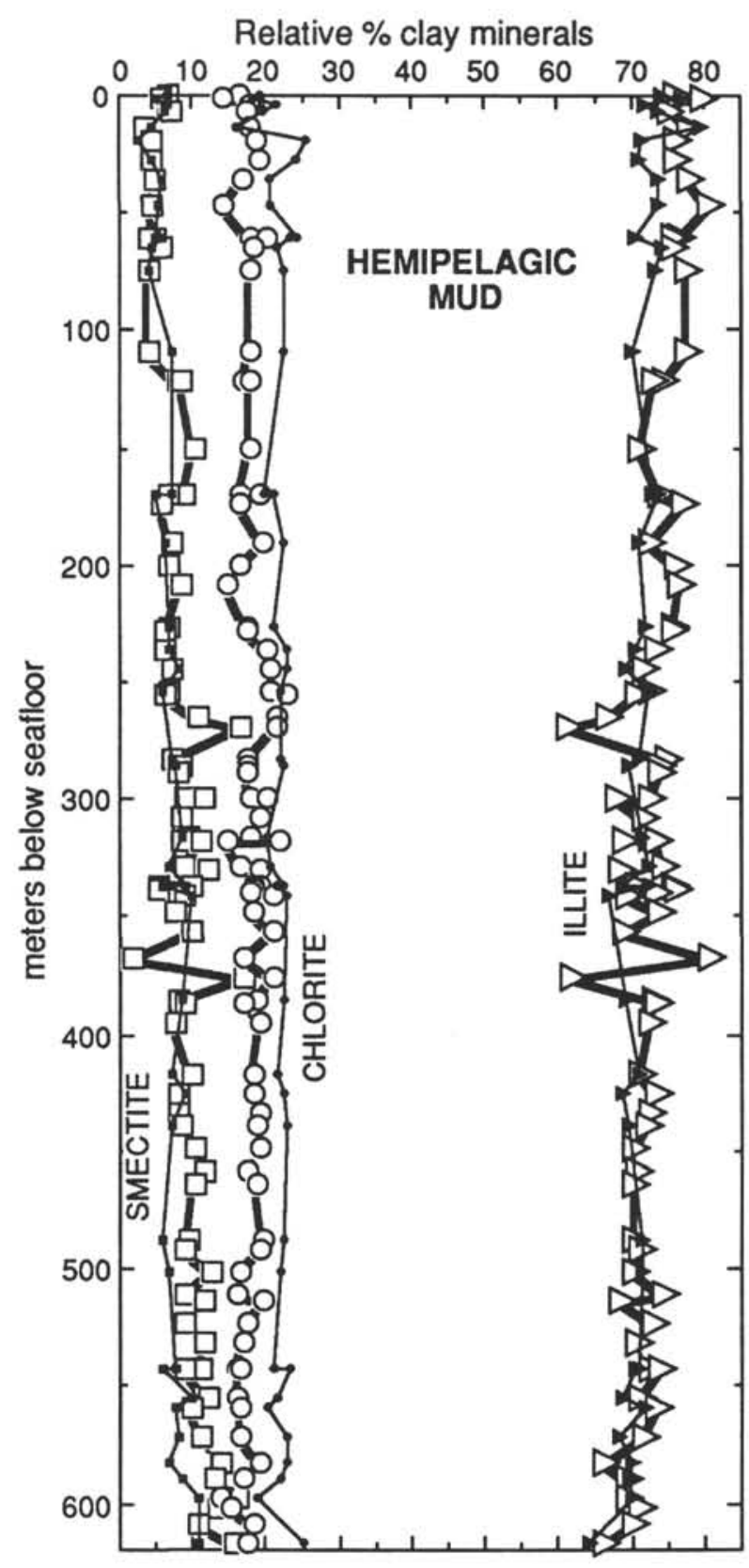

Figure 8. Partitioning of clay minerals as a function of grain size within hemipelagic mud deposits at Site 808. Open symbols and solid lines correspond to the $<2-\mu \mathrm{m}$ size fraction, and the closed symbols and narrow lines depict the 2-6- $\mu \mathrm{m}$ size fraction. Note that the content of chlorite is consistently higher in the coarser size fraction. Values are based on University of Missouri peak-area weighting factors (see Table 1).

mildly metamorphosed subduction complex of Jurassic age (Taira, 1985b). Germane to our investigation, Sassi and Scolari (1974) showed that mica $b_{0}$ values for the Sambagawa Belt fall within a range of 9.040-9.060 $\AA$, and this high phengite content indicates greater $\mathrm{Fe}$ $+\mathrm{Mg}$ substitution in response to a high-pressure metamorphic gradient. If phengitic micas from the Sambagawa schists have been transported south into the Philippine Sea, then the amounts are below the detection level of our analytical techniques. Finally, Underwood et al. (in press) completed measurements of vitrinite reflectance, illite crystallinity, and mica $b_{0}$ lattice spacing for Shimanto strata of Eocene through Miocene age exposed on the Muroto Peninsula of Shikoku

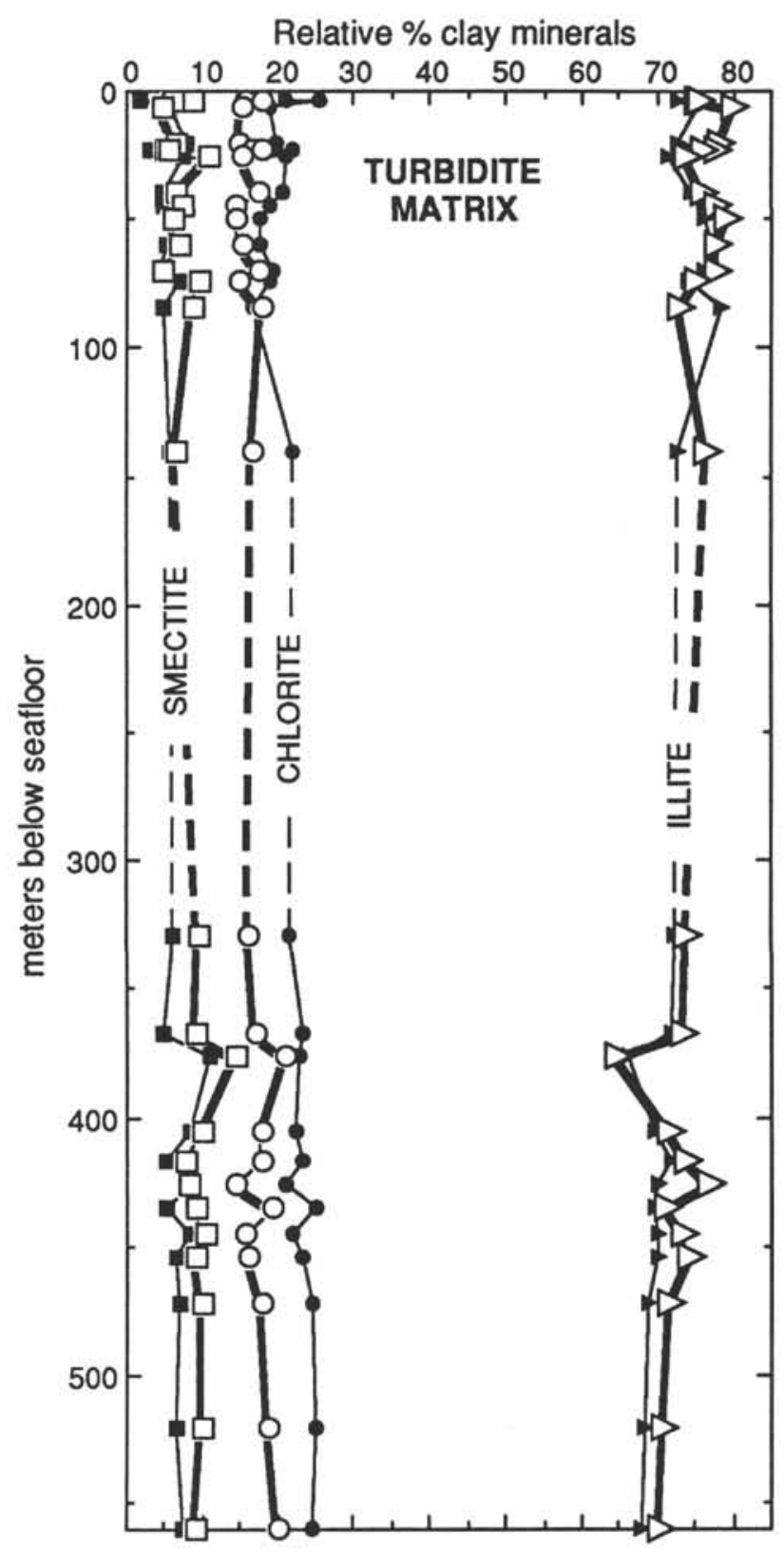

Figure 9. Partitioning of clay minerals as a function of grain size within the matrix of turbidite sands and turbidite silts at Site 808 . Open symbols and solid lines correspond to the $<2-\mu \mathrm{m}$ size fraction, and the closed symbols and narrow lines depict the $2-6-\mu \mathrm{m}$ size fraction. Note that the content of chlorite consistently increases in the coarser size fraction, whereas smectite and illite tend to increase in the finer fraction. Values are based on University of Missouri peak-area weighting factors (see Table 2).

(Fig. 14). In addition, vitrinite reflectance $\left(\mathrm{R}_{\mathrm{o}}\right)$ data are available at a reconnaissance level for the Cretaceous Shimanto Belt farther to the north (Mori and Taguchi, 1988). Some zones of high organic rank $\left(R_{\mathrm{o}}\right.$ $>3.0 \%$ ), epimetamorphism, and advanced anchimetamorphism have been documented in these studies, particularly in proximity to the Miocene intrusive bodies and in the hanging walls of south-verging, out-of-sequence, listric thrusts. Nevertheless, most of the Shimanto strata analyzed to date yield CI values that are too high and/or $R_{o}$ values that are too low to account for the detrital illite population of the Nankai Trough. Although some influx of recycled Shimanto and Sambagawa detritus seems logical, particularly in the context of the 

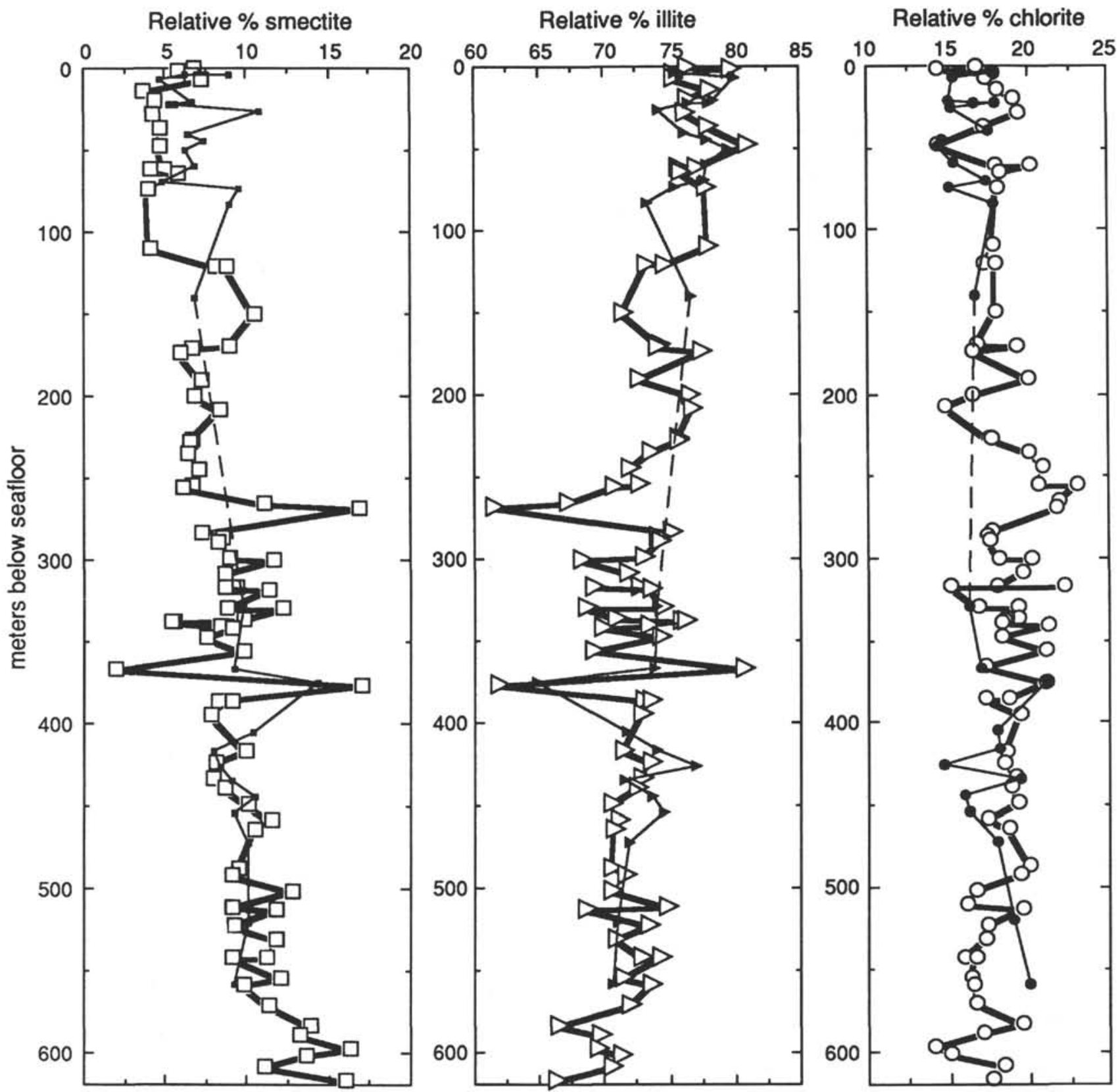

Figure 10. Comparison of relative clay-mineral percentages $(<2-\mu \mathrm{m}$ size fraction $)$ for hemipelagic muds and turbidite matrix at Site 808 . Open symbols and solid lines indicate hemipelagic specimens; closed symbols and narrow lines represent data from turbidite matrix. In general, the interbedded lithologies contain similar clay-mineral assemblages. Values are based on University of Missouri peak-area weighting factors (see Tables 1 and 2).

subaerial and submarine systems of drainage, the clay-sized products of transverse delivery have been masked by debris eroded from the Izu-Honshu collision zone to the east (Fig. 14).

\section{CONCLUSIONS}

Previously published petrographic data have been used to argue that Quaternary and Pliocene turbidite sands in the Nankai Trough depositional system were derived largely from the collision zone that formed between the Izu-Bonin Arc and the Honshu Arc. Unfortunately, these point-count data are not precise enough to yield unequivocal interpretations of sediment provenance, so we have examined clay minerals from both turbidite-matrix samples and hemipelagic mud samples as an independent test of the provenance interpretations. The conclusions listed below pertain only to the lower slope carapace and turbidite wedge of the Nankai Trough (Units I, II, and III at Site 808). Transport of the same clay-mineral suite farther south into the Shikoku Basin seems very likely (Fig. 14). However, because of the complicating effects of clay-mineral diagenesis with depth, we hesitate to extend our conclusions regarding detrital provenance below the base of lithofacies Unit III (i.e., the trench-to-basin transition).

1. Illite is the dominant clay mineral in the Nankai Trough. Relative percentages of all three major mineral constituents (illite, chlorite, and smectite) are remarkably uniform in the turbidite wedge as a function of depth.

2. There are no meaningful differences between the respective clay mineralogies of hemipelagic muds and matrix samples from 


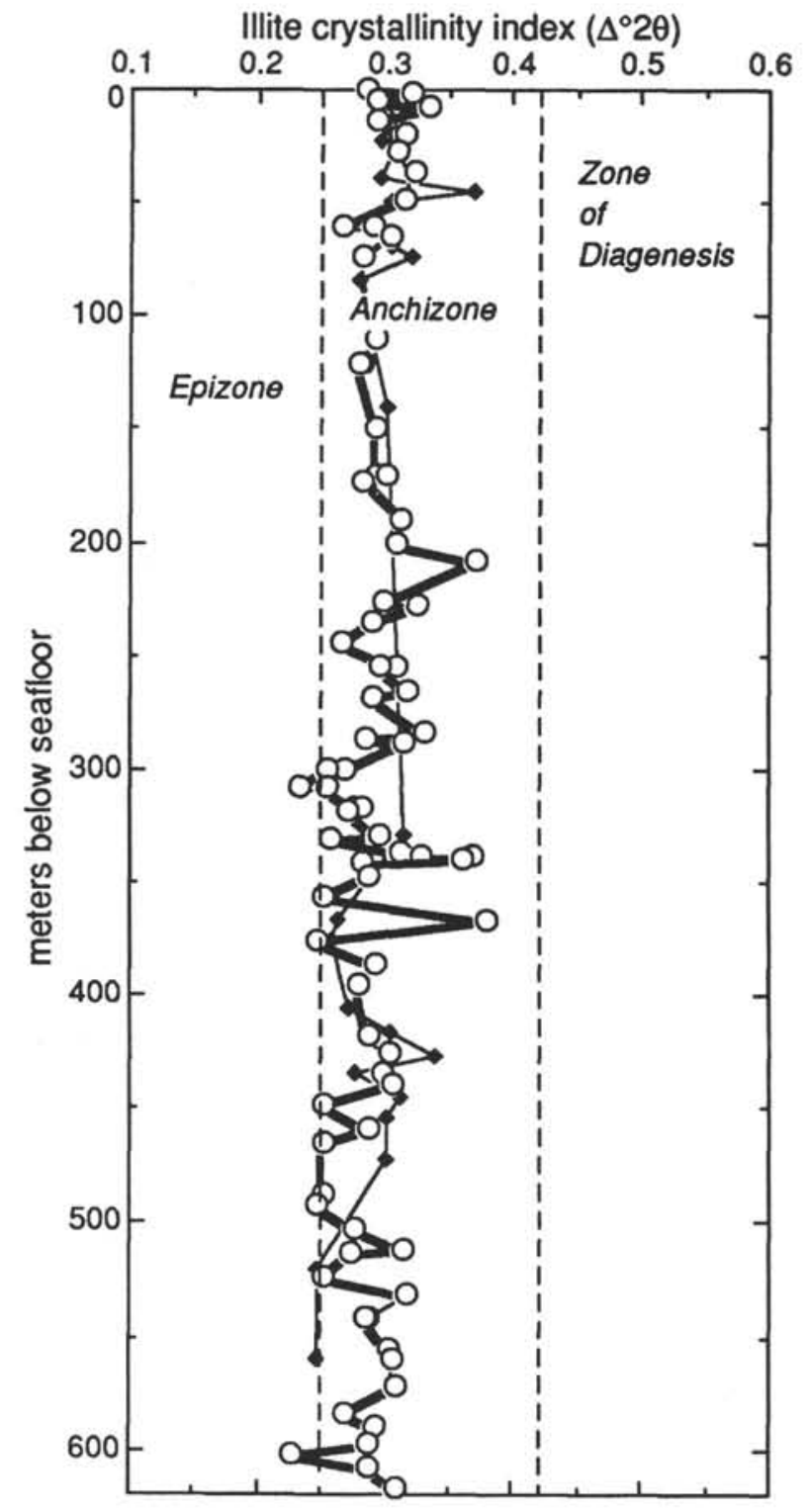

Figure 11. Values of illite crystallinity index $\left(\Delta^{\circ} 2 \theta\right)$ plotted as a function of depth (mbsf) at Site 808. All of these data were obtained from the $<2-\mu \mathrm{m}$ size fraction. Boundaries for the anchizone and epizone are from Blenkinsop (1988) and Kisch (1990).

turbidite sands and silts. Hemipelagic muds deposited from the bottom nepheloid layer and the interstitial clays associated with turbidity currents show the same provenance.

3. A modest amount of mineral partitioning occurs as a function of grain size in both hemipelagic deposits and turbidites. Smectite content increases in the $<2-\mu \mathrm{m}$ size fraction, and chlorite content increases in the $2-6-\mu \mathrm{m}$ size fraction. Illite content increases only slightly with decreasing grain size.

4. Detrital illites mixtures typically yield values of the crystallinity index that correspond to advanced stages of anchimetamorphism and lowermost greenschist-facies metamorphism (epizone). Most specimens, in addition, are dominated by the $2 \mathrm{M}_{1}$ mica polytype, although the $1 \mathrm{Md}$ and $1 \mathrm{M}$ forms are also present. This result is likewise consistent with anchimetamorphic conditions in the source terrane. Mica $b_{0}$ lattice spacings correspond to an intermediate-pressure facies series of metamorphism. There is no evidence to suggest significant influx of material from a zone of high-pressure (blueschist-facies) metamorphism.

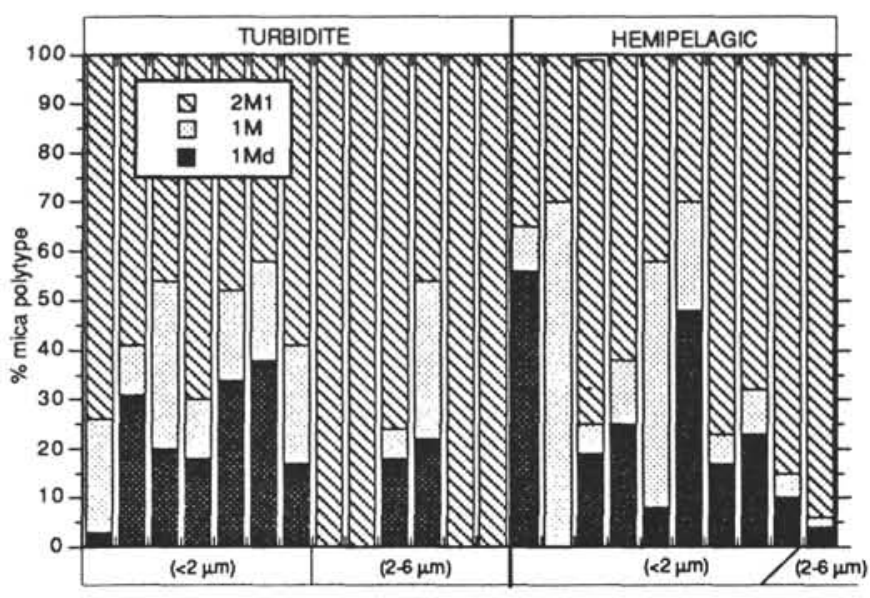

Figure 12. Bar graph showing relative percentages of $1 \mathrm{M}, 1 \mathrm{M} d$, and $2 \mathrm{M}_{1}$ mica polytypes within the detrital illite/muscovite population at Site 808. These data are consistent with the occurrence of anchimetamorphic conditions within the region of detrital provenance. No obvious differences exist between hemipelagic and turbidite deposits, but the $2 \mathrm{M}_{1}$ polytype appears to increase in relative abundance in the $2-6-\mu \mathrm{m}$ size fraction.

5. Paleocurrent data from Site 808 , together with shipboard point-counts of turbidite sands, XRD estimates of clay mineral percentages, and precise characterizations of the detrital illite population, collectively support our contention that the principal detrital source region is located in the Izu-Honshu collision zone. Rock types within the source region include volcanic, sedimentary, and volcaniclastic strata that have been exposed conditions of regional burial metamorphism corresponding to the zeolite, prehnite-pumpellyite, and actinolite-greenschist facies. In addition, the collision zone contains sites of Quaternary volcanic activity, intrusions of quartz diorite, and associated aureoles of contact metamorphism, with alteration grades as high as the amphibolite facies. Most of the polymictic sediments in the Nankai Trough (all size fractions) probably have been eroded from within the Fuji River drainage basin and funneled through the Suruga Trough before entering the trench environment. A subsidiary fraction could be derived from the Tenryu River and submarine canyon system, which is located immediately to the west of the collision zone. The possibility of transverse sediment contributions from rock units such as the Shimanto Belt cannot be eliminated completely, but this component of the regional sediment budget appears to be relatively minor.

6. The regional pattern of sediment dispersal is dominated by southwest-directed axial turbidity currents, radial expansion and oblique movement of suspended clouds onto and beyond the seaward slope of the Nankai Trough, and flow reflection back toward the trench axis. Our ability to trace the mineralogic signature of the source area into the facies units of Shikoku Basin (i.e., Units IV and $\mathrm{V}$ at Site 808 ) is hampered by the effects of clay-mineral diagenesis, and acceleration of diagenetic reactions by conditions of high regional heat flow.

\section{ACKNOWLEDGMENTS}

We thank the crew and staff aboard the JOIDES Resolution for their assistance during sample acquisition. Funding for X-ray diffraction analyses at the University of Missouri was provided by the National Science Foundation through the Joint Oceanographic Institutions, U.S. Science Support Program. Eric Hathon provided instruction in the lab, and Deb Bergfeld completed tests of accuracy for peak-area weighting factors. Kathy Marsaglia and Suzanne O'Connell kindly reviewed the manuscript. 

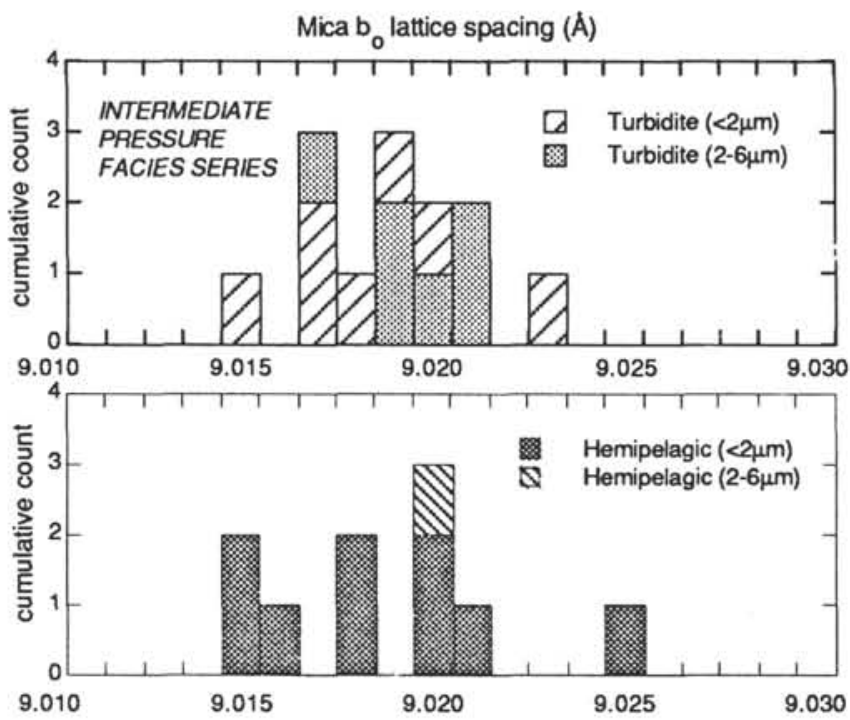

Figure 13. Histograms showing values of mica $b_{\mathrm{o}}$ lattice spacing for the detrital illite/muscovite population at ODP Site 808 . Values within this range indicate modest amounts of phengitic substitution in the muscovite-celadonite solidsolution series (i.e., higher octahedral $\mathrm{Fe}_{10 \text { tal }}+\mathrm{Mg}$ ), which is consistent with a metamorphic facies series of intermediate pressure and low temperature (Guidotti and Sassi, 1986). Note that the micaceous minerals within hemipelagic muds are similar in composition to those in turbidite sands and silts, and there are no obvious changes as a function of grain size within either type of deposit.

\section{REFERENCES}

Agar, S.M., 1990. The interaction of fluid processes and progressive deformation during shallow level accretion: examples from the Shimanto Belt of SW Japan. J. Geophys. Res., 95:9133-9147.

Bachman, S.B., 1982. The Coastal belt of the Franciscan: youngest phase of northern California subduction. In Leggett, J.K. (Ed.), Trench-Forearc Geology. Geol. Soc. London Spec. Publ., 10:401-417.

Banno, S., 1986. The high-pressure metamorphic belts of Japan: a review. In Evans, B.W., and Brown, E.H. (Eds.), Blueschists and Eclogites. Mem.Geol. Soc. Am., 164:365-374.

Biscaye, P.E., 1964. Distinction between kaolinite and chlorite in recent sediments by X-ray diffraction. Am. Mineral., 49:1281-1289.

1965. Mineralogy and sedimentation of recent deep-sea clay in the Atlantic Ocean and adjacent seas and oceans. Geol. Soc. Am. Bull., 76:803-831.

Blake, M.C., Jr., Jayko, A.S., and McLaughlin, R.J., 1985. Tectonostratigraphic terranes of the northern Coast Ranges, California. In Howell, D.G. (Ed.), Tectonostratigraphic Terranes of the Circum-Pacific Region. Circum-Pac. Counc. Energy Mineral. Resour., Earth Sci. Ser., 1:159-172.

Blenkinsop, T.G., 1988. Definition of low-grade metamorphic zones using illite crystallinity. J. Meta. Geol., 6:623-636.

Boggs, S., Jr., 1984. Quaternary sedimentation in the Japan arc-trench system. Geol. Soc. Am. Bull., 95:669-685.

Byrne, T., 1984. Early deformation in melange terranes of the Ghost Rocks Formation, Kodiak Islands, Alaska. In Raymond, L.A. (Ed.), Melanges: Their Nature, Origin, and Significance. Spec. Pap.-Geol. Soc. Am., 198:21-52.

Cadet, J.-P., et al., 1987. The Japan Trench and its juncture with the Kuril Trench: cruise results of the Kaiko project, Leg 3. Earth Planet. Sci. Lett., $83: 267-284$.

Calvert, C.S., 1984. Simplified CsCl-hydrazine-dimethylsulfoxide intercalation of kaolinite. Clays Clay Miner., 32:125-130.

Chamley, H., 1980. Clay sedimentation and paleoenvironment in the Shikoku Basin since the middle Miocene (Deep Sea Drilling Project Leg 58, North Philippine Sea). In Klein, G. deV., Kobayashi, K., et al., 1980. Init. Repts. DSDP, 58: Washington (U.S. Govt. Printing Office), 669-681.

Chamley, H., Cadet, J.-P., and Charvet, J., 1986. Nankai Trough and Japan Trench late Cenozoic paleoenvironments deduced from clay mineralogy data. In Kagami, H., Karig, D.E., Coulbourn, W.T., et al., Init. Repts. DSDP, 87: Washington (U.S. Govt. Printing Office), 633-642.

Chamot-Rooke, N., Renard, V., and Le Pichon, X., 1987. Magnetic anomalies in the Shikoku Basin: a new interpretation. Earth Planet. Sci. Lett., 83:214-228.

Chung, F.H., 1974. Quantitative interpretation of X-ray diffraction patterns of mixtures. I. Matrix flushing method for quantitative multi-component analysis. J. Appl. Crystallogr., 7:519-525.

Cook, H.E., Zemmels, I., and Matti, J.C., 1975. X-ray mineralogy data, far western Pacific, Leg 31 Deep Sea Drilling Project. In Karig, D.E., Ingle, J.C., Jr., et al., Init. Repts. DSDP, 31: Washington (U.S. Govt. Printing Office), 883-895.

Coulbourn, W.T., 1986. Sedimentologic summary, Nankai Trough Sites 582 and 583, and Japan Trench Site 584. In Kagami, H., Karig, D.E., Coulbourn, W.T., et al., Init. Repts. DSDP, 87: Washington (U.S. Govt. Printing Office), 909-926.

Damuth, J.E., 1979. Migrating sediment waves created by turbidity currents in the northern South China Basin. Geology, 7:520-523.

De Rosa, R., Zuffa, G.G., Taira, A., and Leggett, J.K., 1986. Petrography of trench sands from the Nankai Trough, southwest Japan: implications for long-distance turbidite transportation. Geol. Mag., 123:477-486.

Dickinson, W.R., 1985. Interpreting provenance relations from detrital modes of sandstones. In Zuffa, G.G. (Ed.), Provenance of Arenites: Boston (Reidel Publ.), 333-361.

Dickinson, W.R., and Suczek, C., 1979. Plate tectonics and sandstone compositions. AAPG Bull., 63:2164-2182.

DiTullio, L., and Byrne, T., 1990. Deformation paths in the shallow levels of an accretionary prism: the Eocene Shimanto belt of southwest Japan. Geol. Soc. Am. Bull., 102:1420-1438.

Dolan, J., Beck, C., and Ogawa, Y., 1989. Upslope deposition of extremely distal turbidites: an example from the Tiburon Rise, west-central Atlantic. Geology, 17:990-994.

Drever, J.I., 1973. The preparation of oriented clay mineral specimens for $\mathrm{X}$-ray diffraction analysis by a filter-membrane technique: Am. Mineral., 58:553-554.

Ernst, W.G., Seki, Y., Onuki, H., and Gilbert, M.C., 1970. Comparative Study of Low-grade Metamorphism in the California Coast Ranges and the Outer Metamorphic Belt of Japan. Mem.-Geol. Soc. Am., 124.

Frey, M., 1987. Very low-grade metamorphism of clastic sedimentary rocks. In Frey, M. (Ed.), Low Temperature Metamorphism: New York (Chapman and Hall), 9-58.

Griffin, J.J., Windom, H., and Goldberg, E.D., 1968. The distribution of clay minerals in the world ocean. Deep-Sea Res. Part A, 15:433-459.

Guidotti, C.V., and Sassi, F.P., 1976. Muscovite as a petrogenetic indicator mineral in pelitic schists. Neues Jahrb. Mineral. Abh., 127:97-142. 1986. Classification and correlation of metamorphic facies series by means of muscovite $b_{0}$ data from low-grade metapelites. Neues Jahrb. Mineral. Abh., 153:363-380.

Hara, I., Shiota, T., Hide, K., Okamoto, K., Takeda, K., Hayasaka, Y., and Sakuri, Y., 1990. Nappe structure of the Sambagawa belt. J. Meta. Geol., 8:441-456.

Harrold, P.J., and Moore, J.C., 1975. Composition of deep-sea sands from marginal basins of the northwestern Pacific. In Karig. D.E., Ingle, J.C., Jr., et al., Init. Repts. DSDP, 31: Washington (U.S. Govt. Printing Office), 507-514.

Hathon, E.G., and Underwood, M.B., 1991. Clay mineralogy and chemistry as indicators of hemipelagic sediment dispersal south of the Aleutian arc. Mar. Geol., 97:145-166.

Heath, G.R., and Pisias, N.G., 1979. A method for the quantitative estimation of clay minerals in North Pacific deep sea sediments. Clays Clay Miner, 27:175-184.

Hein, J.R., Scholl, D.W., and Gutmacher, C.E., 1976. Neogene clay minerals of the far northwest Pacific and southern Bering Sea. In Bailey, S.W. (Ed.), 1975 Int. Clay Conf. Proc. (Applied Publ. Ltd.), 71-80.

Hibbard, J.P., and Karig, D.E., 1990. Structural and magmatic responses to spreading ridge subduction: an example from southwest Japan. Tectonics, 9:207-230.

Higashino, T., 1990. The higher grade metamorphic zonation of the Sambagawa metamorphic belt in central Shikoku, Japan. J. Meta. Geol., 8:413-423.

Ingersoll, R.V., Bullard, T.F., Ford, R.L., Grimm, J.P., Pickle, J.D., and Sares, S.W., 1984. The effect of grain size on detrital modes: a test of the Gazzi-Dickinson point counting method. J. Sediment. Petrol., 54:103-116.

Johns, W.D., Grim, R.E., and Bradley, W.F., 1954. Quantitative estimations of clay minerals by diffraction methods. J. Sediment. Petrol., 24:242-251. 
Kagami, H., 1985. Internal structures of the accretionary wedge in the Nankai Trough off Shikoku, southwestern Japan. In Nasu, N., et al. (Eds.), Formation of Active Ocean Margins: Tokyo (Terra Sci. Publ. Co.), 193-219.

Kagami, H., Karig, D.E., Coulbourn, W.T., et al., 1986. Init. Repts. DSDP, 87: Washington (U.S. Govt. Printing Office).

Karig, D.E., 1975. Basin genesis in the Philippine Sea. In Karig, D.E., Ingle, J.C., Jr., et al., Init. Repts. DSDP, 31: Washington (U.S. Govt. Printing Office), 857-879.

Karig, D.E., Ingle, J.C., Jr., et al., 1975. Init. Repts. DSDP, 31: Washington (U.S. Govt. Printing Office).

Kisch, H.J., 1987. Correlation between indicators of very low-grade metamorphism. In Frey, M. (Ed.), Low Temperature Metamorphism: New York (Chapman and Hall), 227-300.

1990. Calibration of the anchizone: a critical comparison of illite "crystallinity" scales used for definition. J. Meta. Geol., 8:31-46.

Kisch, H.J., and Frey, M., 1987. Appendix: effect of sample preparation on the measured $10 \AA$ peak width of illite (illite "crystallinity"). In Frey, M. (Ed.), Low Temperature Metamorphism: New York (Chapman and Hall), 301-304.

Klein, G. deV., Kobayashi, K., et al., 1980. Init. Repts. DSDP, 58: Washington (U.S. Govt. Printing Office).

Kneller, B., Edwards, D., McCaffrey, W., and Moore, R., 1991. Oblique reflection of turbidity currents. Geology, 19:250-252.

Kumon, F., Suzuki, H., Nakazawa, K., Tokuoka, T., Harata, T., Kimura, K., Nakaya, S., Ishigami, T., and Nakamura, K., 1988. Shimanto Belt in the Kii Peninsula, southwest Japan. Mod. Geol., 12:71-96.

Le Pichon, X., Iiyama, T., Chamley, H., Charvet, J., Faure, M., Fujimoto, H., Furuta, T., Ida, Y., Kagami, H., Lallemant, S., Leggett, J., Murata, A., Okada, H., Rangin, C., Renard, V., Taira, A., and Tokuyama, H., 1987a. Nankai Trough and fossil Shikoku Ridge results of Box 6 Kaiko Survey. Earth Planet. Sci. Lett., 83:186-198.

1987b. The eastern and western ends of Nankai Trough: results of Box 5 and Box 7 Kaiko survey. Earth Planet. Sci. Lett., 83:199-213.

Marsaglia, K.M., Ingersoll, R.V., and Packer, B.M., in press. Tectonic evolution of the Japanese Islands as reflected in modal compositions of Cenozoic forearc and backarc sand and sandstone. Tectonics.

Maxwell, D.T., and Hower, J., 1967. High-grade diagenesis and low-grade metamorphism of illite in the Precambrian Belt Series. Am. Mineral., 52:843-857.

Minai, Y., Matsumoto, R., and Tominaga, T., 1986. Geochemistry of deep sea sediments from the Nankai Trough, the Japan Trench, and adjacent regions. In Kagami, H., Karig, D.E., Coulbourn, W.T., et al., 1986. Init. Repts. DSDP, 87: Washington (U.S. Govt. Printing Office), 643-657.

Miyake, Y., 1985. MORB-like tholeiites formed within the Miocene forearc basin, southwest Japan. Lithos, 18:23-34.

Moore, D.W., and Reynolds, R.C., Jr., 1989. X-ray Diffraction and the Identification and Analysis of Clay Minerals: New York (Oxford Univ. Press).

Moore, G.F., Karig, D.E., Shipley, T.H., Taira, A., Stoffa, P.L., and Wood, W.T., 1991. Structural framework of the ODP Leg 131 area, Nankai Trough. In Taira, A., Hill, I., Firth, J.V., et al., Proc. ODP, Init. Repts., 131: College Station, TX (Ocean Drilling Program), 15-23.

Moore, G.F., and Shipboard Scientific Party, 1991. Underway geophysics. In Taira, A., Hill, 1., Firth, J.V., et al., Proc. ODP, Init. Repts., 131: College Station, TX (Ocean Drilling Program), 21-23.

Moore, G.F., Shipley, T.H., Stoffa, P.L., Karig, D.E., Taira, A., Kuramoto, S., Tokuyama, H., and Suyehiro, K., 1990. Structure of the Nankai Trough accretionary zone from multichannel seismic reflection data. J. Geophys. Res., 95:8753-8765.

Moore, J.C., Byrne, T., Plumley, P.W., Reid, M., Gibbons, H., and Coe, R.S., 1983. Paleogene evolution of the Kodiak Islands, Alaska: consequences of ridge-trench interaction in a more southerly latitude. Tectonics, 2:265-293.

Moore, J.C., Biju-Duval, B., Bergen, J.A., Blackington, G., Claypool, G.E., Cowan, D.S., Duennebier, F., Guerra, R.T., Hemleben, C.H.J., Hussong, D., Marlow, M.S., Natland, J.H., Pudsey, C.J., Renz, G.W., Tardy, M.E., Wilson, D., and Wright, A.A., 1982a. Offscraping and underthrusting of sediment at the deformation front of the Barbados Ridge: Deep Sea Drilling Project Leg 78A. Geol. Soc. Am. Bull., 93:1065-1077.

, 1982b. Facies belts of the Middle America Trench and forearc region, southern Mexico: results from Leg 66 DSDP. In Leggett, J.K. (Ed.), Trench-Forearc Geology. Geol. Soc. Spec. Publ. London, 10:77-94.

1988. Tectonics and hydrogeology of the northern Barbados Ridge: results from Ocean Drilling Program Leg 110. Geol. Soc. Am. Bull., 100:1578-1593.
Moore, J.C., and Karig, D.E., 1976. Sedimentology, structural geology, and tectonics of the Shikoku subduction zone, southwestern Japan. Geol. Soc. Am. Bull., 87:1259-1268.

Mori, K., and Taguchi, K., 1988. Examination of low-grade metamorphism in the Shimanto Belt by vitrinite reflectance. Mod. Geol., 12:325-340.

Muck, M.T., and Underwood, M.B., 1990. Upslope flow of turbidity currents: a comparison among field observations, theory, and laboratory models. Geology, 18:54-57.

Naef, U., and Stern, W.B., 1982. Some critical remarks on the analysis of phengite and paragonite components in muscovite by $\mathrm{X}$-ray diffractometry. Contrib. Mineral. Petrol., 79:355-360.

Naidu, A.S., and Mowatt, T.C., 1983. Sources and dispersal patterns of clay minerals in surface sediments from the continental shelf areas off Alaska. Geol. Soc. Am. Bull., 94:841-854.

Nakamura, K., Renard, V., Angelier, J., Azema, J., Bourgois, J. Deplus, C., Fujioka, K., Hamano, Y., Huchon, P., Kinoshita, H., Labaume, P., Ogawa, Y., Seno, T., Takeuchi, A., Tanahashi, M., and Vigneresse, J-L., 1987. Oblique and near collision subduction, Sagami and Suruga Troughs - preliminary results of the French-Japanese 1984 Kaiko cruise, Leg 2. Earth Planet. Sci. Lett., 83:229-242.

Nishi, H., 1988. Structural analysis of part of the Shimanto accretionary complex, Kyushu, Japan, based on planktonic foraminiferal zonation. Mod. Geol., 12:47-70.

Oba, N., 1977. Emplacement of granitic rocks in the Outer Zone of southwest Japan and geological significance. J. Geol., 85:383-393.

Ogawa, Y., Horiuchi, K., Taniguchi, H., and Naka, J., 1985. Collision of the Izu arc with Honshu and the effects of oblique subduction in the MiuraBoso Peninsulas. Tectonophysics, 119:349-379.

Ogawa, Y., and Taniguchi, H., 1988. Geology and tectonics of the Miura-Boso Peninsulas and the adjacent area. Mod. Geol., 12:147-168.

Okuda, Y., and Honza, E., 1988. Tectonic evolution of the Seinan (SW) Japan fore-arc and accretion in the Nankai Trough. Mod. Geol., 12:411-434.

Padan, A., Kisch, H.J., and Shagam, R., 1982. Use of the lattice parameter bo of dioctahedral illite/muscovite for the characterization of $\mathrm{P} / \mathrm{T}$ gradients of incipient metamorphism. Contrib. Mineral. Petrol., 79:85-95.

Pickering, K.T., and Hiscott, R.N., 1985. Contained (reflected) turbidity currents from the Middle Ordovician Cloridorme Formation, Quebec, Canada: an alternative to the antidune hypothesis. Sedimentology, 32:373-394.

Piper, D.J.W., von Huene, R., and Duncan, J.R., 1973. Late Quaternary sedimentation in the active eastern Aleutian Trench. Geology, 1:19-22.

Robinson, D., Warr, L.N., and Bevins, R.E., 1990. The illite "crystallinity" technique; a critical appraisal of its precision. J. Meta. Geol., 8:333-344.

Sample, J.C., and Moore, J.C., 1987. Structural style and kinematics of an underplated slate belt, Kodiak and adjacent islands. Geol. Soc. Am. Bull., 99:7-20.

Sassi, F.P., and Scolari, A., 1974. The $b_{0}$ value of the potassic white micas as a barometric indicator in low-grade metamorphism of pelitic schists. Contrib. Mineral. Petrol., 45:143-152.

Scholl, D.W., Hein, J.R., Marlow, M., and Buffington, E.C., 1977. Meiji sediment tongue: North Pacific evidence for limited movement between the Pacific and North American plates. Geol. Soc. Am. Bull., 88:1567-1576.

Schweller, W.J., and Kulm, L.D., 1978. Depositional patterns and channelized sedimentation in active eastern Pacific trenches. In Stanley, D.J., and Kelling, G. (Eds.), Sedimentation in Submarine Canyons, Fans, and Trenches: Stroudsburg (Dowden, Hutchinson, and Ross), 323-350.

Shimamura, K., 1989. Topography and sedimentary facies of the Nankai deep sea channel. In Taira, A., and Masuda, F. (Eds.), Sedimentary Facies in the Active Plate Margin: Tokyo (Terra Sci. Publ.), 529-556.

Shipboard Scientific Party, 1975. Site 297. In Karig, D.E., Ingle, J.C., Jr., et al., 1975. Init. Repts. DSDP, 31: Washington (U.S. Govt. Printing Office), 275-316.

1991a. Geological background and objectives. In Taira, A., Hill, I. Firth, J.V., et al., Proc. ODP, Init. Repts., 131: College Station, TX (Ocean Drilling Program), 5-14.

1991b. Site 808. In Taira, A., Hill, I., Firth, J.V., et al., Proc. ODP Init. Repts., 131: College Station, TX (Ocean Drilling Program), 71-269.

1991c. Explanatory notes. In Taira, A., Hill, I., Firth, J.V., et al., Proc. ODP, Init. Repts., 131: College Station, TX (Ocean Drilling Program), 25-67.

Soh, W., Pickering, K.T., Taira, A., and Tokuyama, H., 1991. Basin evolution in the arc-arc Izu Collision Zone, Mio-Pliocene, Miura Group, central Japan. J. Geol. Soc. London, 148:317-330.

Starkey, H.C., Blackmon, P.D., and Hauff, P.C., 1984. The routine mineralogical analysis of clay bearing samples. U.S. Geol. Surv. Bull., 1563. 
Taira, A., 1985a. Sedimentary evolution of Shikoku subduction zone: the Shimanto Belt and Nankai Trough. In Nasu, N., et al. (Eds.), Formation of Active Ocean Margins: Tokyo (Terra Sci.), 835-851.

1985b. Pre-Neogene accretion tectonics in Japan: a synthesis. Recent Prog. Nat. Sci. Japan, 10:51-63.

Taira, A., et al., 1992. Sediment deformation and hydrogeology of the Nankai Trough accretionary prism: synthesis of shipboard results of ODP Leg 131. Earth Planet. Sci. Lett., 109:431-450.

Taira, A., Hill, I., Firth, J.V., et al., 1991. Proc. ODP, Init. Repts., 131: College Station, TX (Ocean Drilling Program).

Taira, A., Katto, J., Tashiro, M., Okamura, M., and Kodama, K., 1988. The Shimanto Belt in Shikoku, Japan-evolution of Cretaceous to Miocene accretionary prism. Mod. Geol., 12:5-46.

Taira, A., and Niitsuma, N., 1986. Turbidite sedimentation in the Nankai Trough as interpreted from magnetic fabric, grain size, and detrital modal analyses. In Kagami, H., Karig, D.E., Coulbourn, W.T., et al., Init. Repts. DSDP, 87: Washington (U.S. Govt. Printing Office), 611-632.

Taira, A., Okada, H., Whitaker, J.H. McD., and Smith, A.J., 1982. The Shimanto Belt of Japan: Cretaceous-lower Miocene active-margin sedimentation. In Leggett, J.K. (Ed.), Trench-Forearc Geology: Geol. Soc. Spec. Publ. London, 10:5-26.

Terakado, Y., Shimizu, H., and Masuda, A., 1988. Nd and Sr isotopic variations in acidic rocks formed under a peculiar tectonic environment in Miocene SW Japan. Contrib. Mineral. Petrol., 99:1-10.

Thornburg, T.M., and Kulm, L.D., 1987. Sedimentation in the Chile Trench: depositional morphologies, lithofacies, and stratigraphy. Geol. Soc. Am. Bull., 98:33-52.

Toriumi, M., and Arai, T., 1989. Metamorphism of the Izu-Tanzawa collision zone. Tectonophysics, 160:293-303.

Toriumi, M., and Teruya, J., 1988. Tectono-metamorphism of the Shimanto Belt. Mod. Geol., 12:303-324.

Tribble, J.S., 1990. Clay diagenesis in the Barbados accretionary complex: potential impact on hydrology and subduction dynamics. In Mascle, A., Moore, J.C., et al., Proc. ODP, Sci. Results, 110: College Station, TX (Ocean Drilling Program), 97-110.

Underwood, M.B., 1984. A sedimentologic perspective on stratal disruption within sandstone-rich melange terranes. J. Geol., 92:369-386.

-, 1986. Transverse infilling of the central Aleutian Trench by unconfined turbidity currents. Geo-Mar. Lett., 6:7-13.

, 1991. Submarine canyons, unconfined turbidity currents, and sedimentary bypassing of forearc regions. Rev. Aquat. Sci., 4:149-200.
Underwood, M.B., Laughland, M.M., and Kang, S.M., in press. A comparison between organic and inorganic indicators of diagenesis and metamorphism, Upper Shimanto Group, Muroto Peninsula, Shikoku, Japan. In Underwood, M.B. (Ed.), Thermal Evolution of the Tertiary Shimanto Belt, Southwest Japan: An Example of Ridge-Trench Interaction. Spec. Pap.-Geol. Soc. Am., 273.

Underwood, M.B., and Norville, C.E., 1986. Deposition of sand in a trenchslope basin by unconfined turbidity currents. Mar. Geol., 71:383-392.

Valloni, R., 1985. Reading provenance from modern marine sands. In Zuffa, G.G. (Ed.), Provenance of Arenites: Boston (Reidel), 309-332.

von Huene, R., and Arthur, M.A., 1982. Sedimentation across the Japan Trench off northern Honshu Island. In Leggett, J.K. (Ed.), Trench-Forearc Geology. Geol. Soc. Spec. Publ. London, 10:27-48.

von Huene, R., Langseth, M., Nasu, N., and Okada, H., 1982. A summary of Cenozoic tectonic history along the IPOD Japan Trench transect. Geol. Soc. Am. Bull., 93:829-846.

Velde, B., 1965. Phengite micas: synthesis, stability, and natural occurrence. Am. J. Sci., 263:886-913.

Weaver, C.E., and Broekstra, B.R., 1984. Illite-mica. In Weaver, C.E., et al. (Eds.), Shale Slate Metamorphism in the Southern Appalachians: Amsterdam (Elsevier), 67-199.

White, S.M., Chamley, H., Curtis, D., Klein, G. deV., Mizuno, A., and Fountain, D.M., 1980. Sediment synthesis: Deep Sea Drilling Project Leg 58, Philippine Sea. In Klein, G. deV., Kobayashi, K., et al., Init. Repts. DSDP, 58: Washington (U.S. Govt. Printing Office), 963-1013.

Wilson, M.J., 1987. X-ray powder diffraction methods. In Wilson, M.J. (Ed.), A Handbook of Determinative Methods in Clay Mineralogy: New York (Chapman and Hall), 26-97.

Yamano, M., Foucher, J.-P., Kinoshita, M., Fisher, A., Hyndman, R.D., and ODP Leg 131 Shipboard Scientific Party, 1992. Heat flow and fluid flow regime in the western Nankai accretionary prism. Earth Planet. Sci. Lett., 109:451-462.

Yamano, M., Honda, S., and Uyeda, S., 1984. Nankai Trough: a hot trench? Mar. Geophys. Res., 6:187-203.

Yoder, H.S., and Eugster, H.P., 1955. Synthetic and natural muscovites. Geochim. Cosmochim. Acta, 8:225-280.

Date of initial receipt: 4 October 1991

Date of acceptance: 25 June 1992

Ms 131SR-105 


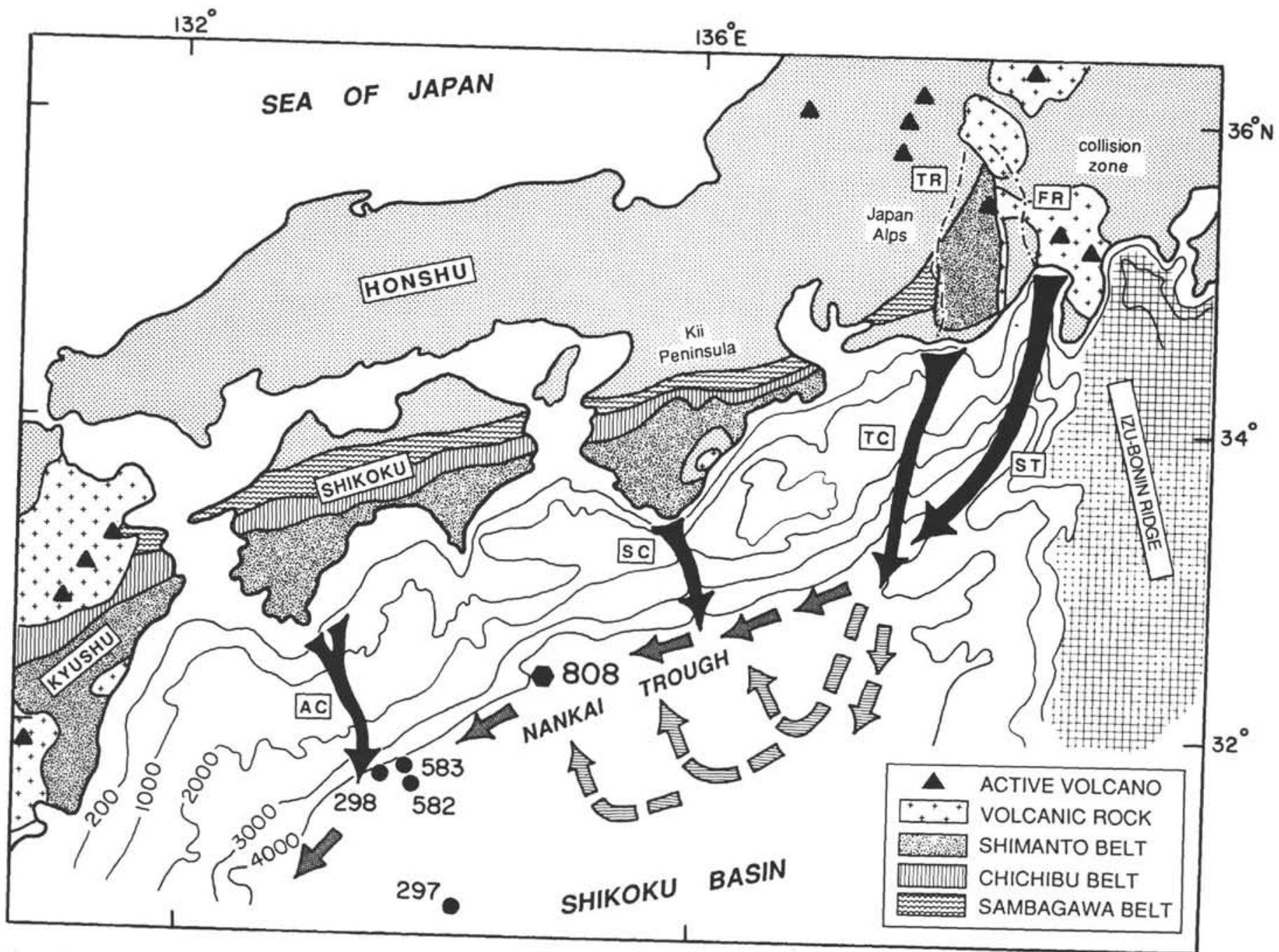

Figure 14. Summary of dispersal pathways and potential provenance regions for sediments of the Nankai turbidite wedge (modified from Taira and Niitsuma, 1986). Large arrows (dark pattern) correspond to major submarine canyons. Smaller arrows depict flow paths (axial, radial, and reflected) within the trench.
Bathymetric contours are in meters. Onshore reguma, composition. FR = Fuji River; TR = Tenryu River; ST of volcanic rock include Neogene through Quaternary units of both felsic and intermediate-to-mafic 